\title{
Prediction of Diagenetic Facies using Well Logs: Evidences from Upper Triassic Yanchang Formation Chang 8 Sandstones in Jiyuan Region, Ordos Basin, China
}

\author{
Jin Lai ${ }^{1}$, Guiwen Wang ${ }^{1,2 *}$, Yu Chai ${ }^{1}$ and Ye Ran ${ }^{1}$ \\ ${ }^{1}$ State Key Laboratory of Petroleum Resources and Prospecting, China University of Petroleum, Beijing, 102249 - China \\ ${ }^{2}$ China University of Petroleum-Beijing, 18 Fuxue Road, Changping District, Beijing, 102249 - China \\ e-mail: sisylaijin@163.com - wanggw@cup.edu.cn - cherrychai213@gmail.com - ranye19910102@sina.com \\ * Corresponding author
}

\begin{abstract}
The eighth member of Upper Triassic Yanchang Formation (Chang 8) is the major oil reservoir unit in Jiyuan oil field, though with the high potential for oil exploration. The Chang 8 sandstones are characterized with low porosity, low permeability and strong microscopic heterogeneities due to the complex deep-burial diagenetic history. Detailed petrological studies by thin section, X-ray diffraction, scanning electron microscopy, core analysis have been used to investigate the lithogology characteristics, diagenesis, diagenetic minerals and their coupling impacts on reservoir property. The results show that Chang 8 sandstones comprise fine to mediumgrained subarkoses, feldspathic litharenites. The pore systems are dominated by remaining primary intergranular pores, secondary dissolution porosity and micropores. Then, five diagenetic facies were divided in Chang 8 sandstones based on the type and degree of diagenesis, diagenetic minerals assemblages and their coupling effects on the reservoir quality. They consist of grain-coating chlorite weak dissolution facies, unstable component dissolution facies, tight compaction facies, clay minerals filling facies and carbonate cementation facies.

The well logging response characteristics of various diagenetic facies are summarized on Gamma Ray (GR), Density Logging (DEN), Acoustic (AC), Compensated Neutron Logging (CNL), and True Formation Resistivity (RT) by translating diagenetic facies to well log responses, the diagenetic facies were defined by a set of log responses, and porosity, permeability ranges for each diagenetic facies were determined from core analyses. Well log data of Luo 13 and Chi 212 are processed to evaluate the accuracy of the predictive model. The diagenetic facies are predicted on the vertical profile based on the generated model. Predicted distribution of diagenetic facies precisely coincide with the microscopic observations, and diagenetic facies in Chang 8 sandstones are generally locally distributed. Tight compaction and carbonate cementation diagenetic facies mainly correspond to the non-reservoir and dry layers of Chang 8 sandstones, layers with higher oil potentials are mainly developed in the grain-coating chlorite weak dissolution and unstable component dissolution diagenetic facies. By translating diagenetic facies to well log responses, diagenetic facies and reservoir properties of intervals that lack core control could be predicted with the same or similar log responses.
\end{abstract}


Résumé - Prédiction de faciès diagénétiques à partir de diagraphies de puits : étude des grès de la formation du Trias supérieur Chang 8 de Yangchang de la région de Jiyuan, bassin d'Ordos, Chine - Le huitième membre de la formation du Trias supérieur de Yangchang (Chang 8) est le principal gisement de pétrole du champ pétrolifère de Jiyuan. Bien qu'offrant un potentiel élevé de prospection pétrolière, les grès de Chang 8 sont caractérisés par une faible porosité, une faible perméabilité et une importante hétérogénéité microscopique dues à une histoire diagénétique complexe liée à un enfouissement profond. Des analyses pétrologiques détaillées de lames minces (par diffractométrie de rayons $\mathrm{X}$, par microscopie à balayage électronique) et de carottes ont été utilisées pour étudier les caractéristiques lithologiques, la diagenèse, les minéraux diagénétiques et leurs incidences sur les propriétés du réservoir. Les résultats indiquent que les grès de Chang 8 sont constitués de litharénites feldspathiques, subarkoses, de taille de grain fine à moyenne. Les systèmes poreux sont dominés par des pores primaires intergranulaires résiduels, une porosité secondaire de dissolution et des micropores. Cinq faciès diagénétiques des grès de Chang 8 ont ainsi été déterminés, selon leur type et degré de diagenèse, les assemblages des matériaux diagénétiques et leurs incidences sur la qualité du réservoir. Ils consistent en un faciès de dissolution faible à tapissage argileux de chlorites, un faciès de dissolution à composante instable, un faciès dense de compaction, un faciès de remplissage en matières argileuses et un faciès de cémentation carbonaté.

Les caractéristiques de réponse des diagraphies de puits de divers faciès diagénétiques ont été résumées en des données Gamma Ray (GR), Density Logging (DEN), Acoustic (AC), Compensated Neutron Logging (CNL), et True Formation Resistivity (RT), en convertissant les faciès diagénétiques en des réponses de diagraphie de puits. Les faciès diagénétiques ont été définis par une série de réponses de diagraphie, tandis que leurs gammes de perméabilité et de porosité ont été déterminées à partir d'analyses de carottes. Les données de diagraphie des puits Luo 13 et Chi 212 ont été traitées afin d'évaluer la précision du modèle prédictif. Le faciès diagénétique est prédit sur un profil vertical à partir du modèle généré. La distribution des faciès diagénétiques ainsi obtenue coïncide avec les observations microscopiques, et les faciès diagénétiques des grès de Chang 8 sont généralement localement distribués. Les faciès denses de compaction et de cémentation carbonatée correspondent principalement aux couches non-réservoir et sèches des grès de Chang 8 , les couches disposant d'un potentiel pétrolifère plus élevé étant principalement constituées des faciès de dissolution faible à tapissage argileux de chlorite et de remplissage en matières argileuses. En convertissant les faciès diagénétiques en des réponses de diagraphie de puits, les faciès diagénétiques et les propriétés de réservoir peuvent être prédits à partir des réponses des diagraphies ou de réponses similaires, sans besoin de contrôle par carottage.

\section{INTRODUCTION}

The North China Craton has been the focus of several recent studies in terms of understanding the geochronologic and tectonic evolution of China and adjacent continental fragments (Ji et al., 2008). The recently discovered Jiyuan oilfield, the focus of this article, is located in the west-central region in Ordos Basin (Fig. 1), and covers an area of about $9500 \mathrm{~km}^{2}$, with a flat strata, a slope of only about $1^{\circ}$ and simple structure, representing a gentle big west dipping monocline (Lai et al., 2013a). The Upper Triassic Yanchang Formation is the dominant Mesozoic oil oil-source rocks and reservoir rocks in ordos Basin (Ji et al., 2008), and the Yanchang Formation consisting mainly of lacustrine, deltaic and fluvial deposits, is divided into Chang 1 ( $1^{\text {st }}$ member of Yanchang Formation) to Chang 10 oil layers (subsections) from bottom to top based on marker beds, lithological association and sedimentary cycles, among these subsections, Chang 7 was deposited in a deep lacustrine environment
(Duan, 2012; Duan et al., 2013), Chang 10 to 7 oil layers were deposited in lake transgression period; Chang 6 to 2 oil layers were deposited in lake regression period; Chang 1 oil layers was deposited during peneplain period (Qiu et al., 2014). The Chang 8 oil layers, were a shallow water delta sedimentary system with many distributary channels. Relatively shallow water, stable tectonic setting, gentle slope and plentiful material sources led to a large set of sandbodies in Chang 8 oil layers vertically superimposed and laterally distributed, creating favorable conditions for large-scale developed reservoir systems and promoting the formation of large scale continuous litho-stratigrahic reservoir in Chang 8 oil layers (Zou et al., 2009; Lai et al., 2013a).

Though with the high potential for oil exploration, the Yanchang Formation, is a typical sandstone reservoir with low porosity, low permeability and strong microscopic heterogeneity, which is famous for known as a whetstone (Zeng and Li, 2009). Diagenetic heterogeneities strongly influence reservoir performance and fluid flow 


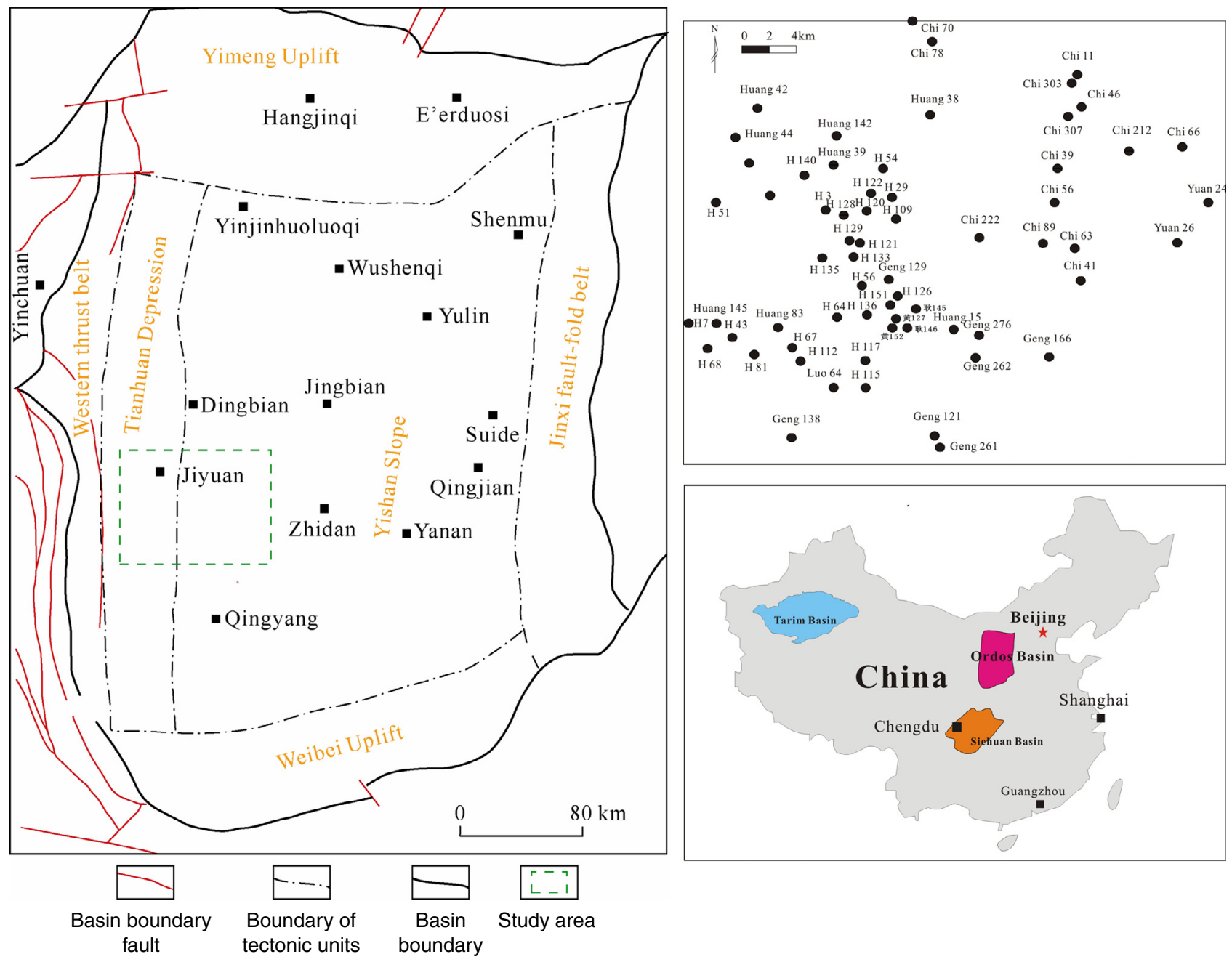

Figure 1

Structural position of the study area (modified after Lai et al., 2013a).

(Deschamps et al., 2012). Effective resource exploitation requires comprehensive reservoir description and characterization to identify the reservoir properties in such diagenetically heterogeneous sandstones (Ozkan et al., 2011), it is of great significance to consider the impact of diagenetic processes and diagenetic minerals on reservoir quality, and this could provide a powerful tool to predict the high quality reservoirs within sandstone successions (Higgs et al., 2007; Ajdukiewicz and Lander., 2010; Morad et al., 2010; Tobin et al., 2010).

Diagenetic facies, which is the combination of types and degree of diagenesis, diagenetic minerals assemblages, determines the formation and distribution of pore type sweet spot in tight sandstones (Zou et al., 2008; Lai et al., 2013a). However, research on diagenetic facies has been confined primarily to core and microscopic thin-section analyses (Zeng et al., 2013), and diagenetic variations have not been previously correlated with well-log responses (Ozkan et al., 2011). However, the diagenetic facies can be defined by a set of log responses, by translating diagenetic facies to well log responses, and the generated model could be used to predict the likely diagenetic facies and reservoir property of intervals that lack core control with the same or similar log responses, or even in nearby wells in a given field.

In this study, we intend to build the diagenetic facies and analyze the dominant factors affecting the reservoir property based on the type and degree diagenesis, diagenetic minerals. Careful microscopic petrographic assessments which are correlation with well log response, i.e., log response characteristics for various diagenetic facies, are built by core to $\log$ calibration, and porosity and permeability ranges for each diagenetic facies were determined from core analyses. The model generated can be used to predict the likely diagenetic facies in a single well which lack core control. 


\section{GEOLOGIC SETTING}

\subsection{Basin Evolution}

The Ordos Basin is one of the largest sedimentary basins that contains huge proven geologic reserves of petroleum resources in China (Zhu et al., 2008). It is located in the western part of the North China block with an area of $320000 \mathrm{~km}^{2}$ (Liu et al., 2004; Zhu et al., 2008). The Ordos Basin is bordered to the north, east, south, and west by the Yin, Luliang, Qinling, Liupan, and Helan mountains, respectively, it is rectangular in shape and trending in a north-south direction (Zhu et al., 2008; Zou et al., 2013a; Qiu et al., 2014). It can be divided into six first-order tectonic units, i.e., the Yimeng Uplift in the north, the fault-fold belt on the west margin, the Tianhuan Depression in the west, the Shanbei Slope in the center, the Weibei Uplift in the south, and the Jinxi Flexural Fold Belt inthe east (Fig. 1) (Li et al., 2008; Jiang et al., 2012; Guo, 2013). The Ordos Basin is a dustpan-like basin with a gentle slope in the east and a steep slope on the west, and it plunges from northwest to southeast (Ji et al., 2010). The study area, Jiyuan Area, is located in the west-central region in Ordos Basin (Lai et al., 2013a). The basin, in areas where large faults and folds were not developed, is a smooth monocline with an east-to-west dip angle of less than $1^{\circ}$ (Zeng and Li, 2009; Duan et al., 2008). As an oldest typical cratonic basin rich in oil and gas in central China, the Ordos basin developed on the Archean granulites and lower Proterozoic greenschists of the North China block (Yang et al., 2005; Jiang et al., 2012), and the evolution of the basin during PaleozoicMesozoic can be divided into three stages: Cambrian-Early Ordovician cratonic basin with divergent margins; Middle Ordovician-Middle Triassic cratonic basin with convergent margins; and Late Triassic-Early Cretaceous intraplate remnant cratonic basin (Yang et al., 2005). During the Late Triassic, the basin was subjected to major changes from marine facies and transitional facies to terrestrial facies because of the Indo-Sinian tectonic movements, and then became an inland depressed basin (Ji et al., 2010; Zou et al., 2013a).

Two hydrocarbon systems as the Paleozoic gas and Mesozoic oil systems are present in the basin (Yang et al., 2005), abundant oil resources are present in the Upper Triassic Yanchang Formation, which is part of a lake-delta sedimentary system with a thickness of $1000-1500 \mathrm{~m}$ (Zeng and Li, 2009). The Liupan Mountains thrust onto the southwestern Ordos area during the Late Triassic, and then resulted in the formation of the southwestern Ordos foreland depression, and the cessation of thrusting and subsequent erosion of the Liupan Mountains at the end of the Late Triassic, thus leading to isostatic rebound of the Ordos basin, which produced a regional unconformity between the Triassic and the Jurassic in the basin (Yang et al., 2005). However, due to its rigid basement, the basin has not been strongly folded and deformed though with the margins of basin having experienced intense tectonic movements (Yang et al., 2005).

\subsection{Stratigraphy and Depositional Facies}

Mesozoic stratigraphy of the Ordos basin and adjacent regions has been well documented in the Chinese literature (Fig. 2) (Guo et al., 2012; Zeng and Li, 2009). The Ordos Basin becomes an isolated lake basin during the Middle and Late Triassic, and a series of lacustrine and deltaic clastic sediments was deposited in the basin during this time, known as the Yanchang Formation (Ji et al., 2008). The disconformable contacts are located between the base of the Yanchang Formation and the Middle Triassic Zhifang Formation and between the top of the Yanchang Formation and the Lower Jurassic Yan'an Formation or Fuxian Formation (Ji et al., 2010). The Yanchang Formation can be subdivided into three main depositional facies: lacustrine, deltaic and fluvial from bottom to up (Luo et al., 2009). The formation contains mainly shallow lacustrine and coal-bearing deltaic deposits. The sedimentation of the Chang 7 to Chang 8 subsections occurred during the main development of the lake when the basin was extending quickly and lake water was deepening (Ji et al., 2010). The Chang 8 sandstones were mainly deposited in underwater distributary channels and mouth bars at the delta front (Lai et al., 2013a), formed in a very flat, shallow and wide intracratonic depression, without a distinct shelf/slope break, mudstones and siltstones constitute the nonreservoir floodplain and playa facies. In a shallow lacustrine, it is not favorable for the preservation of mouth bar sandbodies, so the underwater distributary channel sandstones are the skeletal sandbodies for Chang 8 sandstones (Zou et al., 2009).

\subsection{Petroleum Systems}

Through intensive hydrocarbon exploration and research over several decades in the Ordos basin, a major breakthrough of discovering a significant quantity of hydrocarbons in the basin has recently been made (Zhu et al., 2008; Shuai et al., 2013). It is confirmed that there are abundant petroleum resources in the Ordos basin, continuously distributed over a large area: the Jurassic-Triassic petroleum system, and the Upper Paleozoic and Lower Paleozoic natural gas systems (Shuai et al., 2013; Zou et al., 2013b). The mudstones and oil shales of the Chang 7 subsection are thought to be the best source rocks for Jurassic-Triassic petroleum system (Duan, 2012), the source rocks contain dominantly type I (oil prone) organic matters, with Ro values of $0.66-1.07 \%$ (Yang et al., 2005). The Chang 6 and Chang 8 are the main reservoirs in Jiyuan oilfield (Fig. 2). 


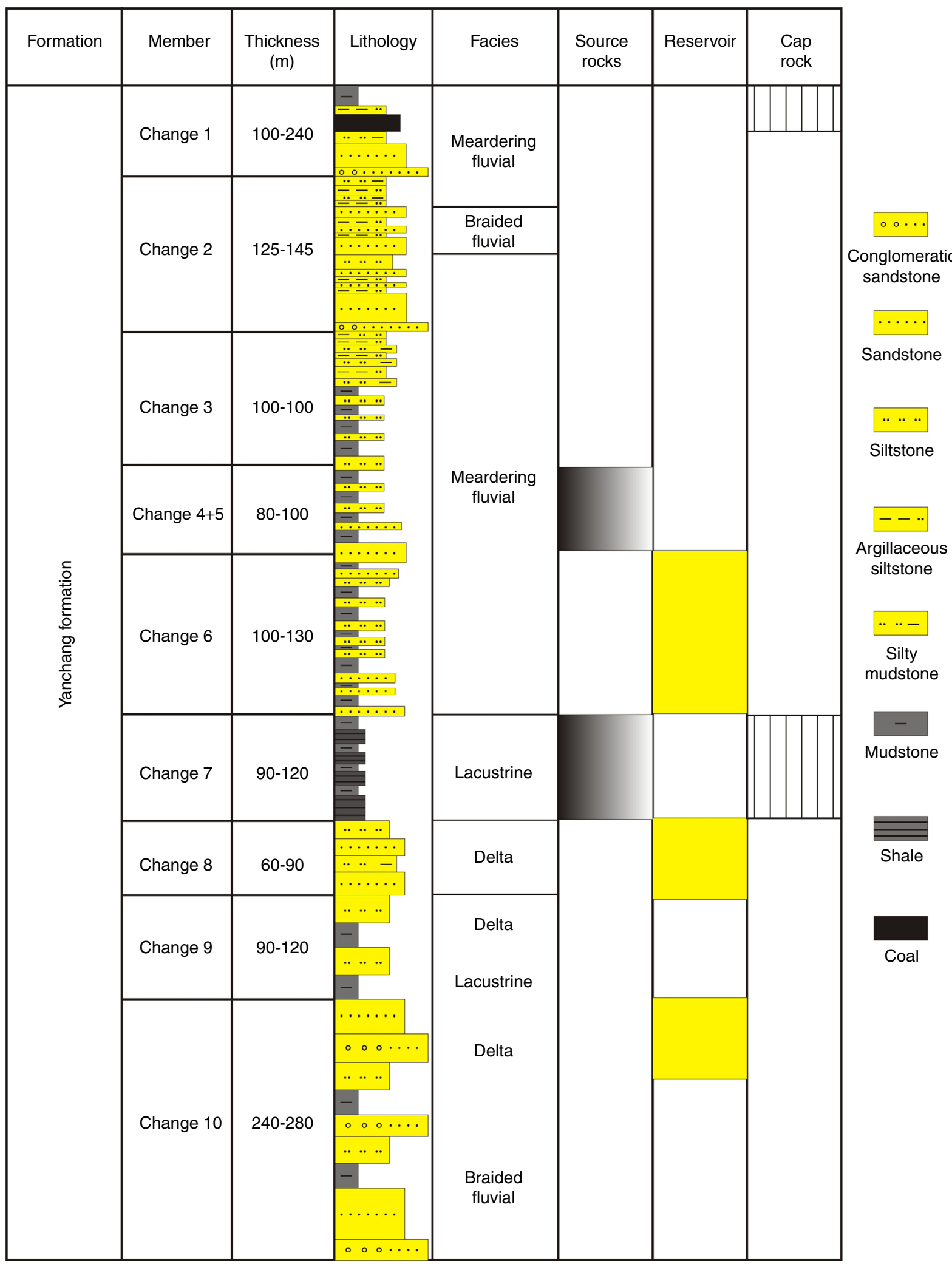

Figure 2

Typical stratigraphic section of the Yanchang Formation, Upper Triassic from the Ordos basin (Modified after Dou et al., 2010; Guo et al., 2012; Zeng and Li, 2009). 
The burial depth of the Chang 8 sandstones ranges from 2200 to $3000 \mathrm{~m}$, with an average of $2600 \mathrm{~m}$. The Upper Triassic deltaic sandstones and overlying shallow-lacustrine and swamp mudstones form a reservoir-seal association (Yang et al., 2005). Chang 7 mudstones and shale form direct seals for Chang 8 sandstones (Guo et al., 2012), deposition of mudstones about $100 \mathrm{~m}$ thick in extensive swamp and shallow-lacustrine environments during the deposition of the upper part of the Yanchang Formation, serve as a regional seal of the Triassic oil pools (Yang et al., 2005).

The Ordos basin is characterized by a stable tectonic setting, most Triassic oil pools are characterized by stratigraphic traps, including the sandstone pinch-out traps controlled mainly by the updip pinch-out of sandstones into mudstones and the truncation traps (Yang et al., 2005). Oil-source correlation shows that the occurrence of the reservoir (Chang 8) immediately above the source-rock (Chang 7) provides an ideal setting for downward petroleum migration, the over-pressure associated with hydrocarbon generation in the source rocks are assumed to be the main driving forces for oil migration and accumulation in Chang 8 tight reservoirs (Guo et al., 2012). Developed on the stable North China Craton block, the Ordos basin has experienced little tectonic deformation since the Palaeozoic (Zhu et al., 2008), indicating a good condition for preservation of petroleum resources.

\section{MATERIALS AND ANALYTICAL METHODS}

Standard modern wire-line logs run in the study area comprises Gamma-Ray (GR), Spontaneous Potential (SP), Bulk Density (DEN), Compensated Neutron (CNL), BoreholeCompensated sonic (AC), Resistivity Logging (RT and $\mathrm{Rxo}$ ), and the core-to-log depth matching is done by correlating the GR signature with the core description.

Core samples and some cuttings samples representative of non-cored intervals were collected from 53 wells. Diagenesis and petrophysical properties were interpreted from petrographic data and core analyses. A total of 957 samples analysis of He-porosity and air permeability were obtained from 53 cored wells. The core plug helium porosity and air permeability were measured at confining pressures of $800 \mathrm{psi}(5.5 \mathrm{MPa})$ net effective stress.

XRD analysis was performed on both bulk and clay fractions of 31 representative sandstone samples, with the aim to identify the clay-mineral species, I/S mixed-layer ratio, and the content of matrix and cements.

A Cathode Luminescence (CL) analyses were performed on polished thin sections using a Technosyn cold cathode luminoscope with the aim to characterize different cement generations and to characterize the origin of detrital quartz grains. The acceleration voltage was $20 \mathrm{kV}, 200-400 \mathrm{~mA}$.
Scanning Electron Microscope (SEM) has been used to confirm the identification of the different clay minerals, to determine the pore structure and the mode of clay occurrence within the pore spaces in the reservoir core samples. Three hundred freshly broken rock fragments coated with a thin layer of gold were examined with a JEOL JSM-T330 SEM equipped with a BackScattered Electron (BSE) detector. Scanning electron microscope analyses of thin section and bulk rock samples were conducted at 15 to $20 \mathrm{kV}$ acceleration voltages with beam currents of 1 and $0.6 \mathrm{nA}$, respectively.

Lithological characteristics as the textural modal grain size and sorting parameters of Chang 8 sandstones were determined through petrographic analysis of the thin sections under planepolarized and cross-polarized light. Representative thin sections (sections containing no thin-sectioning-induced holes or fractured grains, $30 \mu \mathrm{m}$ in thickness) examined with a petrographic microscope, were point counted (300 points per sample) to calculate the relative amounts of detrital framework grains, matrix, authigenic cements, interstitial minerals, and porosity. Pores were identified as primary intergranular pores or secondary (intergranular or intragranular) pores that formed by dissolution of a framework grain.

To examine the volume and distribution of porosity, some (about 240) well prepared thin sections were impregnated with blue-dye resin. To distinguish the mineralogy of carbonate cements, they are stained with Alizarin Red S and potassium ferricyanide for identification of dolomites, ferroan calcite, and nonferroan calcite in thin sections.

\section{RESULTS}

\subsection{Lithology and Well Log Data of the Chang 8 Sandstones}

The lithologies of Chang 8 sandstones are mainly composed of grey medium to fine-grained sandstones (Fig. 3a, b) interbedded with black mudstones (Fig. 3c). Parallel bedding and wedge-shaped cross bedding are commonly seen from the core observations (Fig. 3a, b), which represent a relatively high water energy, while the horizontal bedding can be seen in the mudstones (Fig. 3c). Sometimes, trough cross bedding can also be observed in the fine-grained sandstones (Fig. 3d).

The sandstones are often characterized by a box-shape on the GR logging curves, while the black mudstones always have typical high GR readings, representing of a weaker water dynamic condition (Fig. 4).

\subsection{Sandstones: Texture and Composition}

The Chang 8 sandstones are classified as subarkoses, feldspathic litharenites, and litharenites according to Folk's classification scheme (Folk, 1974) (Fig. 5). The average 


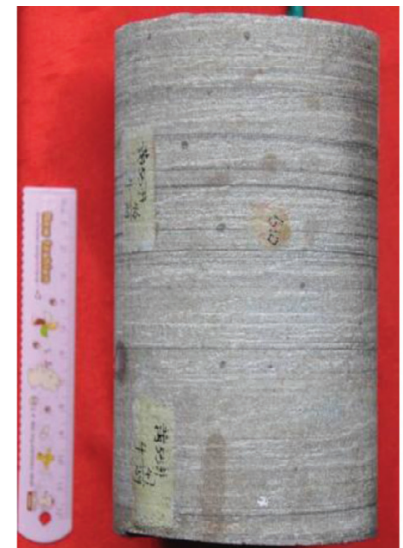

a)

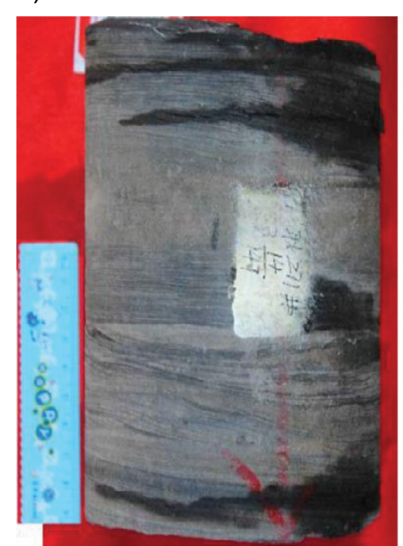

c)

Figure 3

Core photos showing the lithology and sedimentary structure characteristics of Chang 8 sandstones. a) Grey sandstones with parallel bedding, well Huang 55, 2337.27 m; b) Grey sandstones with wedge-shaped cross bedding, well Luo15, $2337.27 \mathrm{~m}$; c) Black mudstones with horizontal bedding, Geng 271, $2505.00 \mathrm{~m}$; d) Grey fine-grained sandstones with trough cross bedding, Geng 271, $2274.78 \mathrm{~m}$.

framework composition of the sandstones is $\mathrm{Q}_{27.9} \mathrm{~F}_{28.5} \mathrm{~L}_{43.6}$ (Fig. 5). The sandstones are lithic-rich and plot mostly in the magmatic-arc field on a Qp-Lvm-Lsm ternary diagram of Dickinson and Suczek (1979). Quartz (mostly monocrystalline) ranges from $10 \%$ to $46.5 \%$ with an average of $28 \%$, Feldspar content varies from $5 \%$ to $47 \%$ average as $29 \%$, consisting of both plagioclase and smaller amount of $\mathrm{K}$-feldspar, while the rock fragments range from $13 \%$ to $74 \%(43 \%)$, and the main types of rock fragments consist mainly of metamorphic rock fragments and volcanic rocks. On average the sandstones are fine- to medium-grained, typically non-equant and moderately to well sorted, grain shape is subrounded to subangular, the types of grain contacts are dominated by planar (Fig. 6a), some samples show concaveconvex grain contacts due to its abundance in soft rock fragments (Fig. 6b). Interstitial material content is relatively high, the matrixes (mainly clay minerals) content ranges from $1 \%$ to $20 \%$, averaged as $6.58 \%$, while the cements content is $5.1 \%$ averaged (ranges, trace-26.3\%). Generally the sandstones are a sery of terrestrial clastic rocks with low compositional maturity but moderate petrological textural maturity.

\subsection{Porosity, Permeability and Pore Systems}

According to the conventional plug analysis of 957 samples, porosity ranges from $1.03 \%$ to $19.50 \%$, with an average of $9.53 \%$, horizontal permeability ranges from 0.004 to $78.75 \mathrm{mD}$, averaged as $0.914 \mathrm{mD}$ (Fig. 7). Relationships between permeability and porosity are described by power-law regressions, and this correlation is not high. Reservoirs characterized by high porosity and low permeability are present, possibly reflecting microporosity and poorly connected pores, suggesting that the permeability is unrelated to the total porosity but rather controlled by pore and throat types, radius and its assemblage. However there are some samples (in the low-porosity/high-permeability area) fractured to enhance permeability.

Thin section analyses (presence of red epoxy) and SEM photomicrographs indicate that pore systems in Chang 8 sandstones are dominated by a combination of micro$(<10 \mu \mathrm{m})$ and mesopores (10 to $62 \mu \mathrm{m})$ and poorly connected macropores. Pore types present in the Chang 8 sandstones are of primary and secondary (intergranular, intragranular and moldic) origin, in addition to the remaining primary intergranular porosity (Fig. 6c, d), variable amounts of secondary intragranular porosity due to partial to pervasive dissolution of detrital framework grains (feldspars and rock fragments) occur in many sandstones (Fig. 6e, f). Intercrystalline micropores are mainly associated with the pore-filling authigenic clays as kaolinite (Fig. 6g), few micro-fractures with low aperture can be seen from SEM observations (Fig. 6h).

Total thin-section porosity of the sandstones, reveals a wide range from trace to $12.50 \%$ with an average of $3.75 \%$. The primary intergranular porosity reveals a range from trace to $12.0 \%$, averaged as $2.29 \%$, whereas the secondary porosity, which was derived from partial to complete dissolution of framework grains, reveals a narrow range from trace to $4.30 \%$.

\subsection{Petrography, Geochemistry and Distribution of Diagenetic Minerals}

The main diagenetic processes affecting the Chang 8 sandstones are compaction, authigenesis of quartz, carbonates, and clay minerals, and dissolution and replacement of detrital grains. Authigenic quartz, authigenic feldspar, clays 


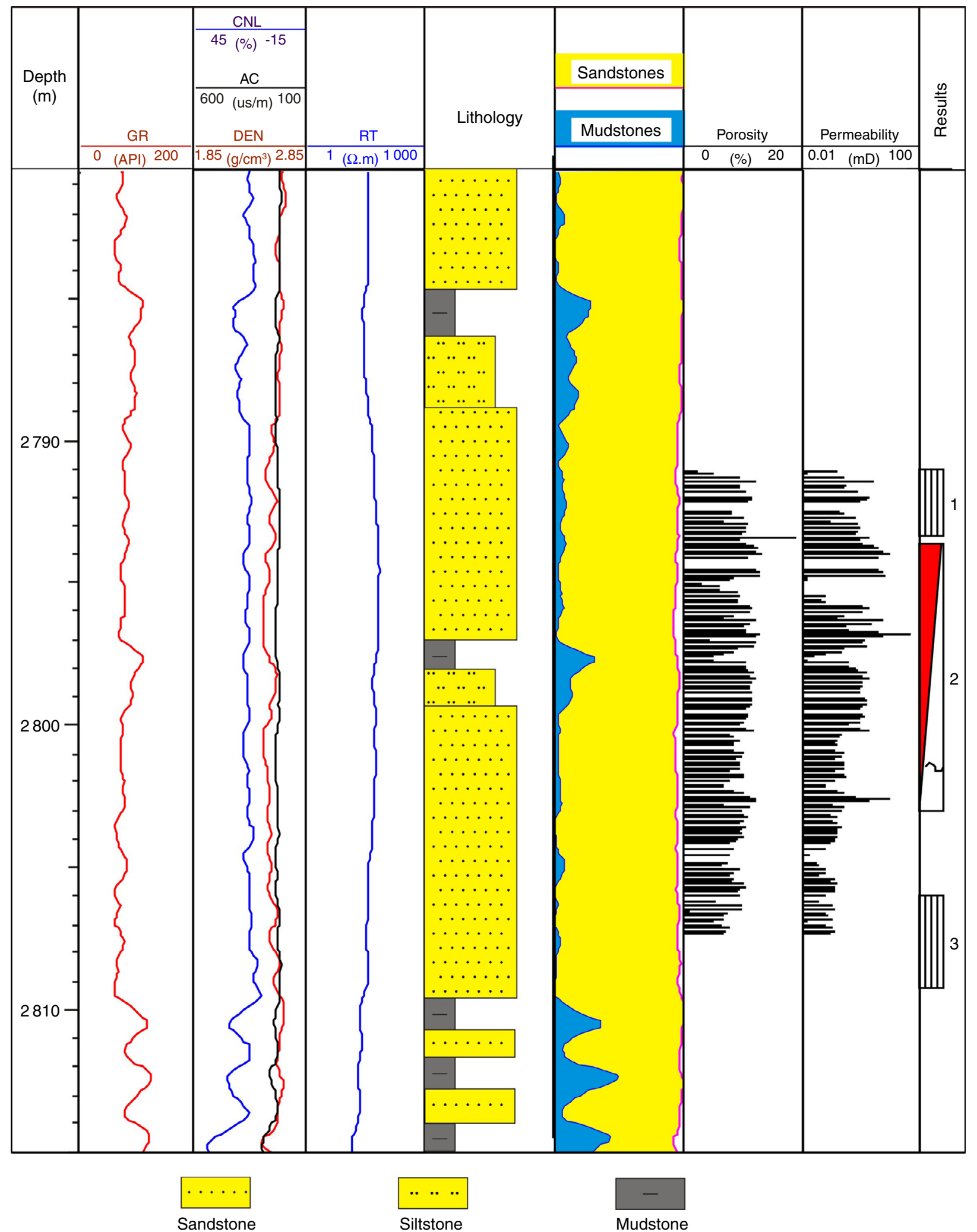

Figure 4

Detailed sedimentary log of the Chang 8 sandstones in a reference well (Geng 166). 


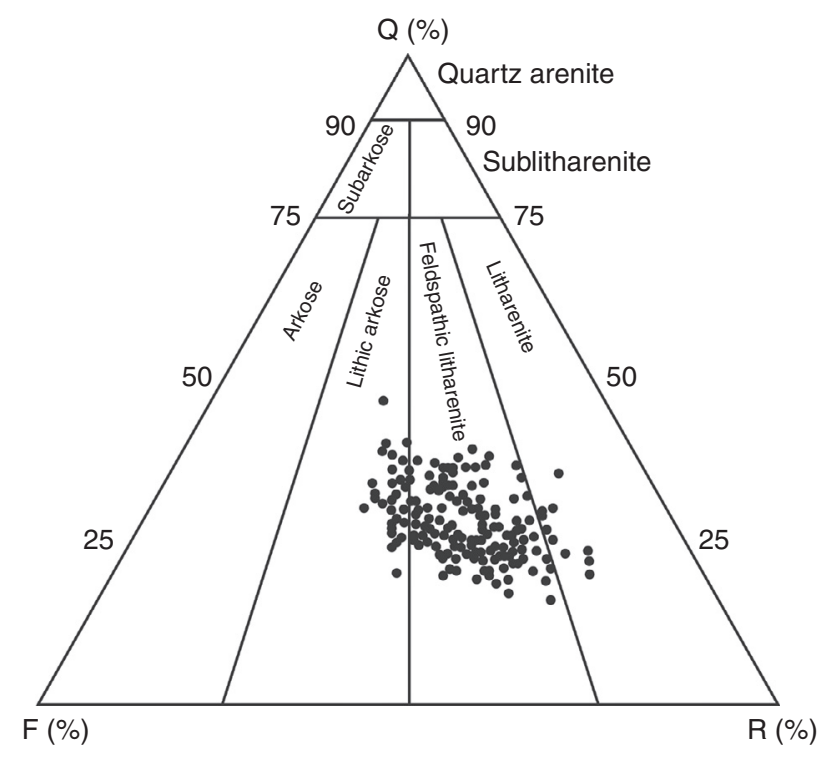

Figure 5

Triangular ternary diagram showing the framework-grain composition of Chang 8 sandstones.

(authigenic and detrital) and carbonates (calcite and dolomite) are the major pore-filling constituents in Chang 8 sandstones, others such as zeolite and authigenic feldspars are present locally.

\subsubsection{Carbonates}

Carbonate is a common cementing material in siliciclastic rocks (Loyd et al., 2012), among them, calcite and Fe-calcite are one of the major cement types in Chang 8 sandstones (Fig. 8a), ranging in abundance from trace amounts to $26.3 \%$ of the rock, with an average of $2.14 \%$, dolomite and late-stage Fe-dolomite is relatively less common (ranges, trace to $10.5 \%$, averaged as $1.5 \%$ ) (Fig. $8 \mathrm{~b}$ ). The Chang 8 sandstones show dominantly two types of calcite cements:

- microcrystalline calcite, which replaces the framework grains (mainly feldspars) and tends to fill large intergranular pores between loosely packed framework grains (Fig. 8a);

- sparry calcite is medium- to coarse grained, which occurs as blocky and poikilotopic, small pores-filling in tightly packed sandstones, or in some cases, replaced the detrital grains (Fig. 8b).

Samples which are tight cemented by carbonate, have very low thin section porosity (Fig. 8a, b). Ferroan dolomites also replaced other components, such as feldspar and rock fragments grains (Fig. 8c).

\subsubsection{Quartz}

Quartz overgrowths are important reservoir quality deteriorating mechanisms in many deep petroleum reservoirs (Islam, 2009). The quartz cements (trace to 7.5\%; av. $1.53 \%$ ) are very common in Chang 8 sandstones (Fig. $8 \mathrm{~d}$, e), they occur as syntaxial overgrowths (Fig. 8d) filling the remained porosity among the grains with concave-convex contacts (Fig. 8e), in which the quartz grains display evidence of pressure dissolution. SEM examination revealed that quartz overgrowths also occur as prismatic outgrowths coexisting with clay layers (Fig. 8f).

\subsubsection{Kaolinite}

SEM examination showed that kaolin occurs mainly as kaolinite, with the characteristic vermicular or "booklet" aggregates composed of several platelets; kaolinite occurs both as pore filling cements and as a replacement products of feldspars (Fig. 8g). The total clays reported by XRD reveal that the clay minerals in these samples are illite, mixed-layer illite/smectite, chlorite and kaolinite. The kaolinite content ranges from trace to $69.44 \%$ with an average of $31.83 \%$, based on XRD and SEM analyses; vermiform kaolinite persists (Fig. 7e, 8g) around detrital aluminous silicates showing traces of dissolution, however, there are still a few samples showing the alteration of kaolinite (Fig. 8h).

\subsubsection{Illite and I/S Mixed Layers}

X-ray diffraction indicates that authigenic clays of Chang 8 sandstone consist of illite and mixed-layer illite/smectite (3.14 to $61.54 \%$; av. $21.67 \%$ ). Based on XRD and SEM analyses, pore-lining illite displays fibrous and hair-like crystals around the detrital grain surfaces, and in some cases, illite extends and bridges the pores, the fibrous and webby morphology of illite and I/Smixed layer blocks pore throats or bridges pores (Fig. 8i), they played a strong role in controlling the reservoir quality.

\subsubsection{Chlorite}

Chlorite is the most abundant clay mineral identified by XRD and SEM measurements (16.99 to $96.86 \%$; av. $54.71 \%$ ); previous studies confirmed that authigenic chlorite is mainly present in three forms as grain coatings, porelining cement, and pore-filling cements (Nguyen et al., 2013). The pore lining and filling chlorite with the rose or flocculus morphology are very common under SEM observations (Fig. 8j, k). Another type of chlorite, grain coating chlorite, is universally known because of its mechanisms for inhibiting quartz precipitation thus better preserving primary porosity for Chang 8 sandstones (Wang et al., 2011; Shi et al., 2011). 


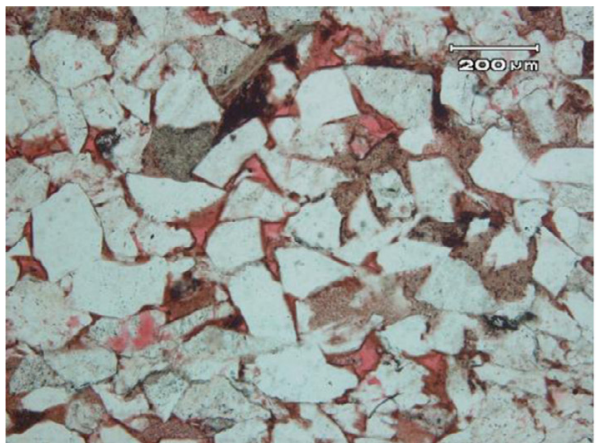

a)

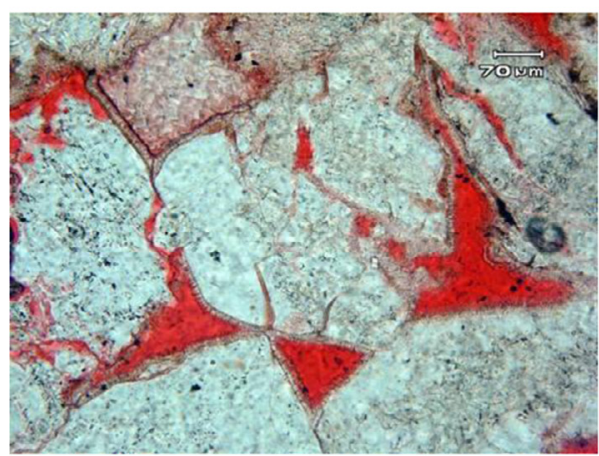

c)

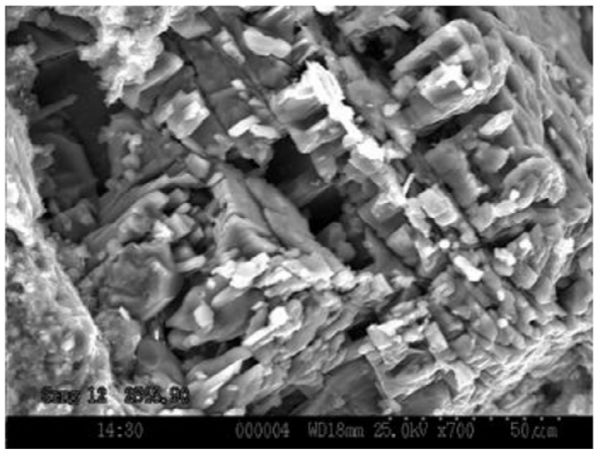

e)

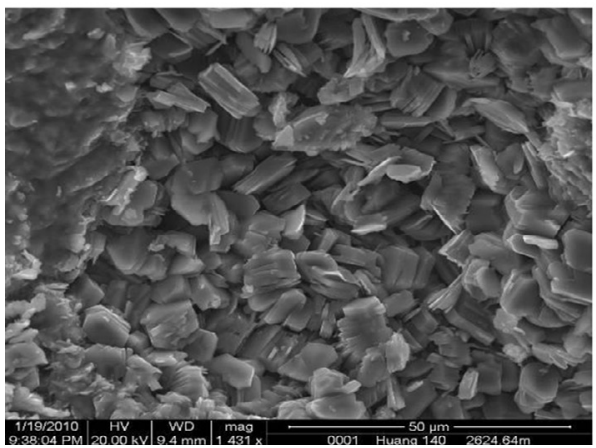

g)

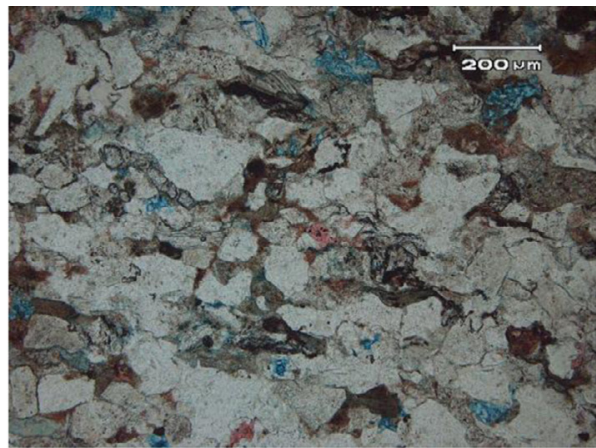

b)

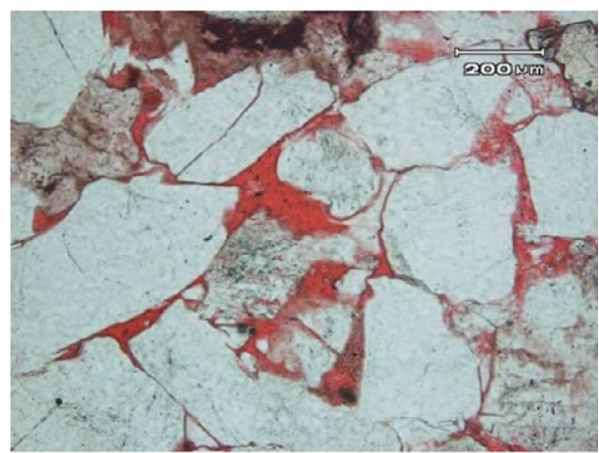

d)

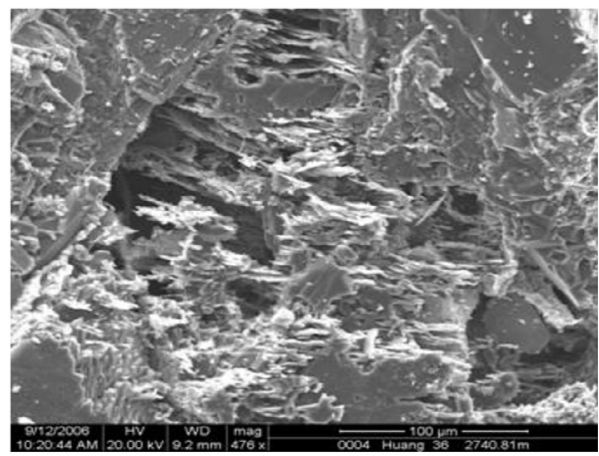

f)

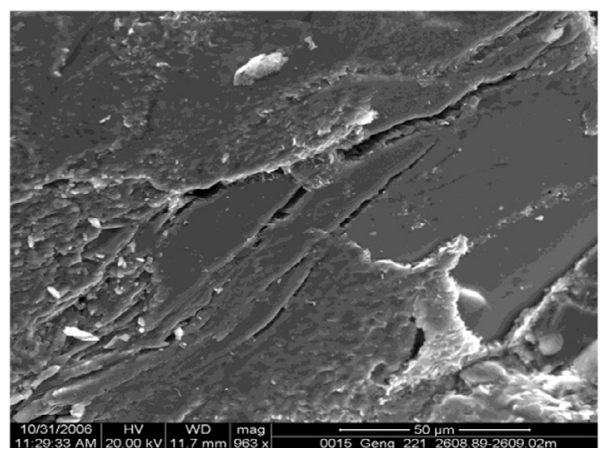

h)

Figure 6

Lithology characteristics and reservoir pore space of Chang 8 sandstones: a) medium-grained, subrounded to subangular, well sorted sandstone, grains exhibit planar grain contacts, Well Geng 212, $2523.51 \mathrm{~m}$, Plane-Polarized Light (PPL); b) medium-grained, well sorted sandstone, framework grains are heavily compacted due to its abundance in soft rock fragments, as indicated by the common planar and concave-convex grain contacts, Well Yuan 43, $2277.06 \mathrm{~m}$, PPL; c) primary intergranular pores showing the irregular polygon morphology, Well Hu 148, 2 632.0 m; d) primary intergranular pore coexisting with the moldic pore, Chi 38, $2525.2 \mathrm{~m}$, PPL; e) dissolution of K-feldspar along its cleavage, Geng 12, $2643.9 \mathrm{~m}$; f) secondary dissolution pores due to partly dissolution of rock fragments, Huang 36, $2740.8 \mathrm{~m}$; g) SEM analysis reveals that intercrystalline pore exists in the kaolinite Well Huang 140, 2624.64 m, SEM, 1431×; h) micro-fracture, Well Geng 221, 2608.89 m, SEM. 


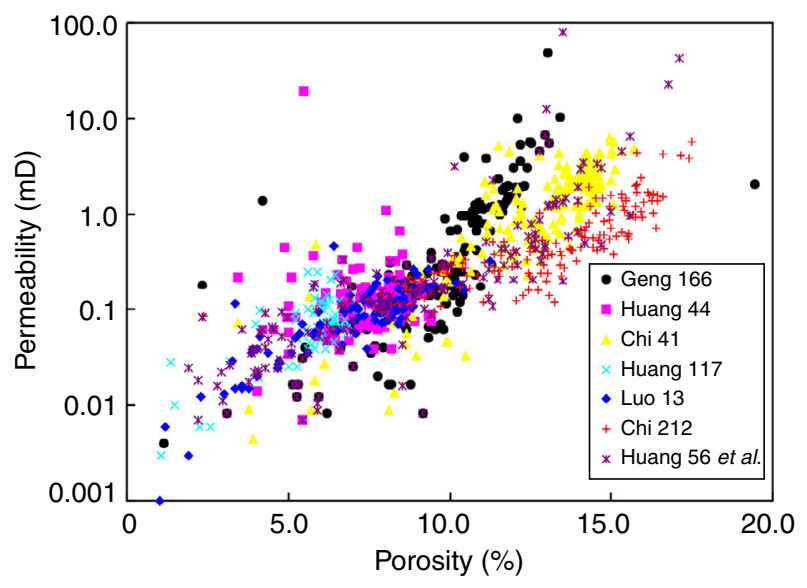

Figure 7

Porosity versus permeability crossplot sorting by wells.

Well-developed grain-coating chlorite forms barriers for further secondary quartz cementation on detrital quartz grains (Fig. 81). The importance of grain coating chlorite in preserving porosity has been recognized in many studies (Bloch et al., 2002; Ehrenberg et al., 2009; Ajdukiewicz and Lander, 2010; Tobin et al., 2010; Taylor et al., 2010; Ozkan et al., 2011; Deschamps et al., 2012; Nguyen et al., 2013). For Chang 8 sandstone, where chlorite rims are present, the formation of quartz overgrowths is actually inhibited and thus porosity being preserved (Fig. 81, m).

\subsubsection{Feldspars}

It is evident from microscopic observation that feldspar underwent a significant degree of dissolution or alteration (Fig. 8n, o). Feldspar overgrowth and authigenic feldspar are rarely seen. The development of secondary porosity (intergranular or intragranular) as the common diagenetic feature largely depends on the leaching of feldspar as detrital grain. Leaching of feldspar grain helps to the development of secondary porosity, feldspars commonly show honeycomb morphology under SEM observations due to dissolution along its cleavage (Fig. 8p). In addition to the minor remaining primary intergranular porosity, variable amounts of secondary porosity occur mainly resulting from the partial to pervasive leaching of feldspar and rock fragments that are of great importance for Chang 8 tight sandstones.

\subsection{Compaction and Sandstone Porosity}

Various cements (carbonates, clay minerals and quartz) as well as compaction have collectively controlled the reservoir quality evolution of the sandstones (Lima and De Ros, 2002;
Mansurbeg et al., 2008). A plot of total InterGranular Volume (IGV; also termed minus-cement porosity) versus total intergranular cement and pseudomatrix (Fig. 9, assuming that the sandstones had an initial porosity of $40 \%$ using tables from Beard and Weyl (1973) for medium-grained, moderately sorted sandstones) indicates that the loss of depositional porosity was greater due to compaction than to cementation, with the exception of a few samples. The greater role of compaction than cementation is attributed to the immature compositional maturity, or presence of relatively small amounts of rigid grains (quartz) capable of preventing mechanical compaction.

\section{DISCUSSIONS}

\subsection{Diagenetic Facies}

Generally, diagenetic facies is a terminology that describes and characterizes the result of sediments subject to certain diagenesis and evolution under the diagenesis (Zou et al., 2008; Lai et al., 2013a). Diagenetic facies usually consists of two aspects, namely diagenetic environment and diagenetic minerals in this environment, and reflects current condition of sedimentary rocks (Zou et al., 2008; Lai et al., 2013b). Diagenetic facies is a combination of some or more diagenetic alterations and proper reservoir spaces to describe the effects on reservoir property (Lai et al., 2013a, c). It represents the final condition of the sediments after diagenesis like corrosion, cementation and compaction (Zou et al., 2008), which is also a sign of characterizing reservoir property, type and merits. Therefore, high-quality diagenetic reservoir related to reservoir capacity can be confirmed further by studying the diagenetic facies, which can manage petroleum exploration more effectively (Zou et al., 2008). For specific sedimentary microfacies, diagenetic facies, together with diagenetic minerals assemblages, decide the formation and distribution of high quality reservoirs in tight sandstones (Lai et al., 2013a). Research of diagenetic facies is helpful for comprehensive evaluation and "sweet spot" prediction of reservoirs (Fu et al., 2009; Lai et al., 2013a).

Chang 8 oil layers in the study area had experienced many types of diagenesis during buried diagenetic evolution. The reservoir quality is mainly related to variation of the types and degrees of diagenesis and diagenetic minerals assemblages. Framework grains in Chang 8 sandstones are generally heavily compacted, as indicated by the dominance of planar and concave-convex grain contacts; some samples characterized by medium-grained, high content of rigid grains and well sorted display limited mechanical compaction. Total cements content is $5.1 \%$ averaged, indicating that the loss of depositional porosity was greater due to compaction than to cementation (Fig. 9). Moldic and vuggy 
porosities are commonly found under microscopic observation, and honey-comb porosities resulting from feldspar dissolution can also be observed from SEM (Fig. 7, 8). These secondary porosity is of great importance to the storage and producibility of hydrocarbon of Chang 8 sandstones. Generally speaking, porosity was decreased by compaction and cementation and then increased by alteration or dissolution of the metastable dissolution of the alumino-silicates grains.
On the basis of the above research on type and degree of diagenesis, diagenetic minerals of Chang 8 oil layers, were divided in five types of diagenetic facies including grain-coating chlorite-weak dissolution diagenetic facies (Fig. 10a, b), unstable component dissolution diagenetic facies (Fig. 10c, d), three destructive diagenetic facies including tight compaction diagenetic facies (Fig. 10e, f), clay minerals (mainly kaolinite) filling diagenetic facies

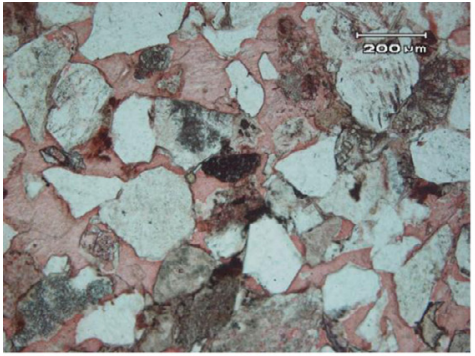

a)

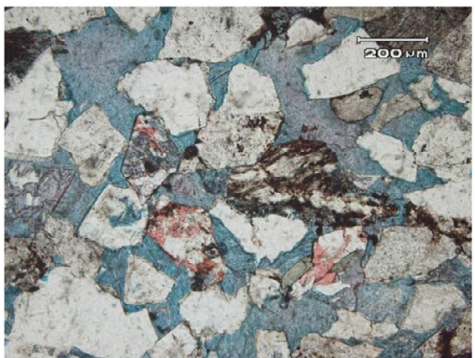

c)

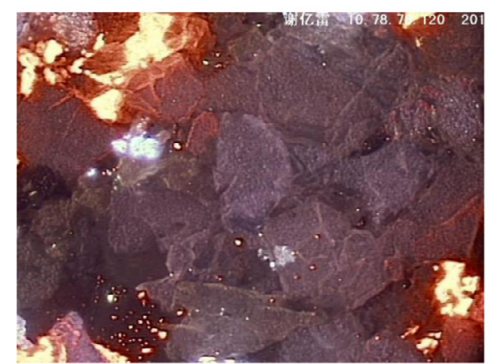

e)

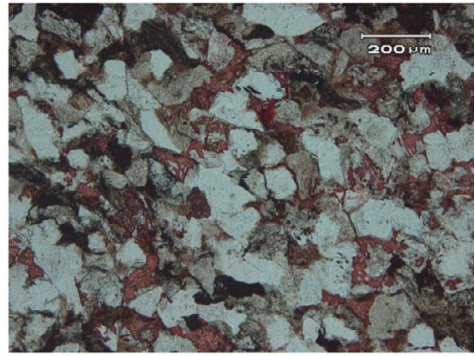

b)

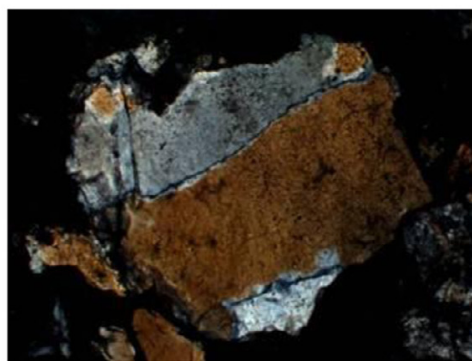

d)

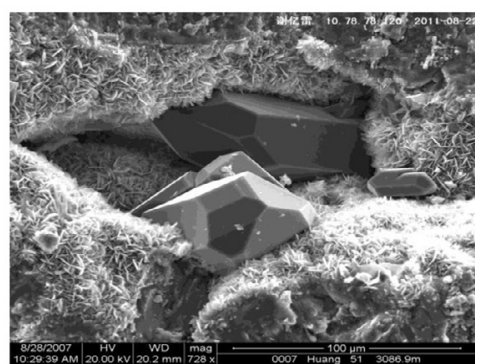

f)

Figure 8

Photomicrographs showing the microscopic diagenetic minerals of Chang 8 reservoirs in Jiyuan region: a) calcite fill large intergranular pores between loosely packed framework grains and replaces the framework grains, Yuan 180, $2346.01 \mathrm{~m}$, PPL; b) poikilotopic calcites filling in small pores in tightly packed sandstones, and replaced the detrital grains, An 62, $2396.47 \mathrm{~m}$, PPL; c) Fe-dolomite (stained blue) cements are common, the porosity is very low, Yuan 181, $2043.7 \mathrm{~m}$, (PPL); d) syntaxial quartz overgrowth, Feng 6, $2565.3 \mathrm{~m}$, cross-polarized light, XPL; e) syntaxial quartz overgrowth, quartz is shown in brown, calcite present a bright red-orange, Geng 166, $2791.77 \mathrm{~m}$, Cathode Luminescence (CL); f) residual intergranular pores filled by authigenic quartz cement, Huang 51, 3086.9 m, SEM; g) SEM images showing vermicular kaolinite aggregate with kaolinite platelets, Huang 129, 2524.18 m; h) SEM images showing slight alteration of vermicular kaolinite, Yuan 26, 2 652.34 m, SEM; i) SEM images showing pore-bridging morphology of illite blocks pore throats, Geng 80, $2808.6 \mathrm{~m}$; j) SEM images showing pore lining and pore filling chlorite, Chi 41, $2612.98 \mathrm{~m}$; k) SEM images showing pore lining and pore filling chlorite, Luo 57, $2684.69 \mathrm{~m}$; 1) SEM images showing grain coating chlorite, the primary porosity is then preserved, Chi $41,2612.98 \mathrm{~m} ; \mathrm{m}$ ) the primary porosity (irregular polygon) is preserved, thin chlorite developed on the edge of particles, Luo 34, $2481.5 \mathrm{~m}$, PPL; n) dissolution of feldspars, Luo 38, $2700.63 \mathrm{~m}$, PPL; o) intragranular pores formed by dissolution of feldspars, Geng 79, $2557.2 \mathrm{~m}$, SEM; p) leaching of feldspar grain which helps to the development of secondary porosity, dissolution of feldspar along its cleavage, honeycomb like pores, Huang 140, 2624.64 m, SEM. 


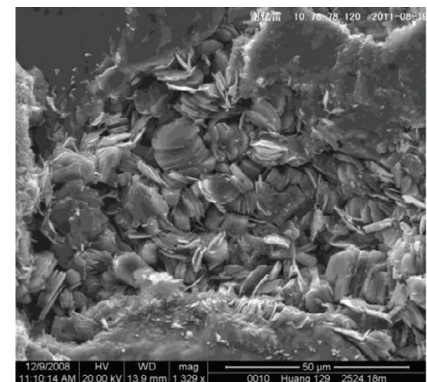

g)

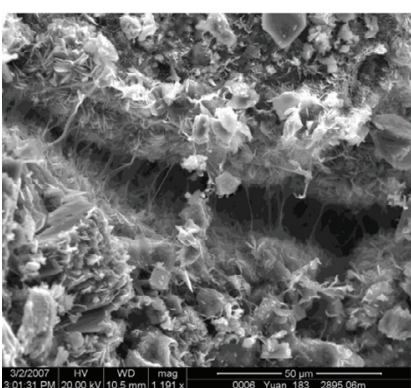

i)

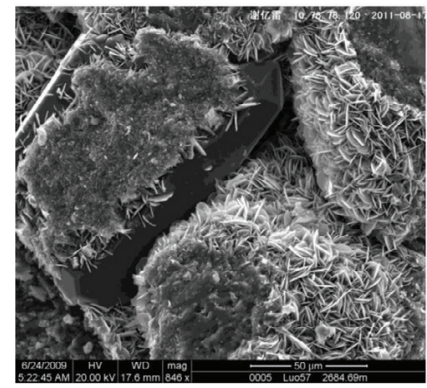

k)

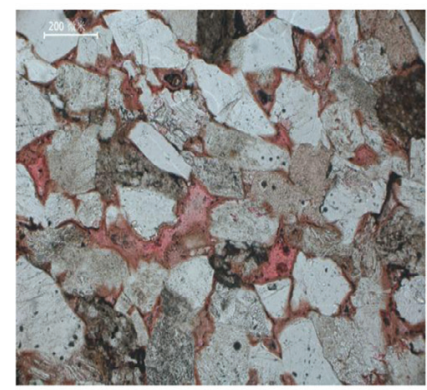

m)

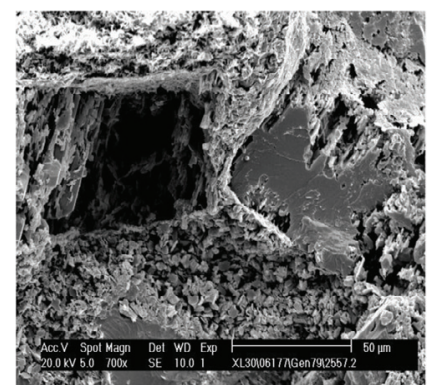

o)

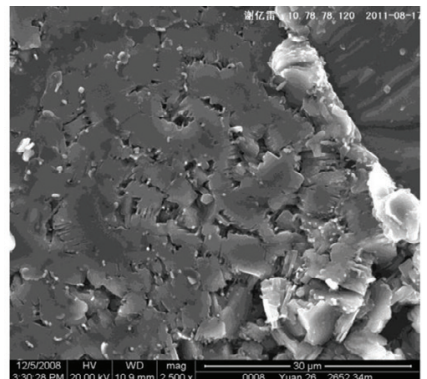

h)

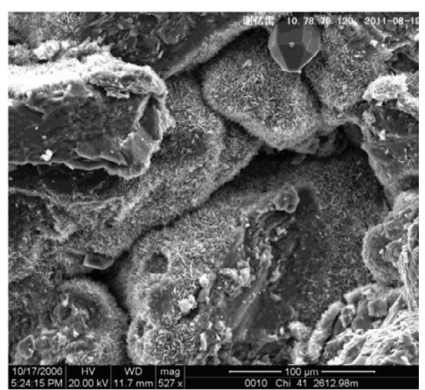

j)

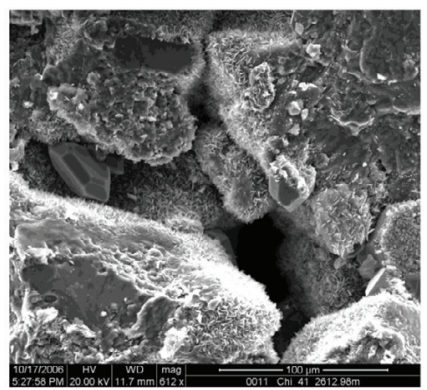

I)

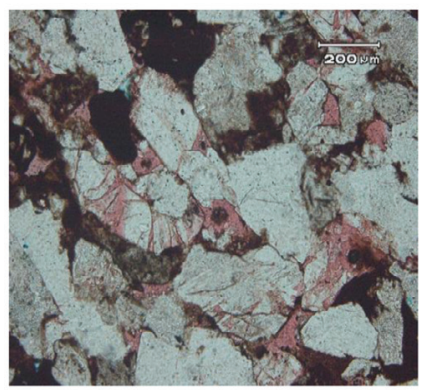

n)

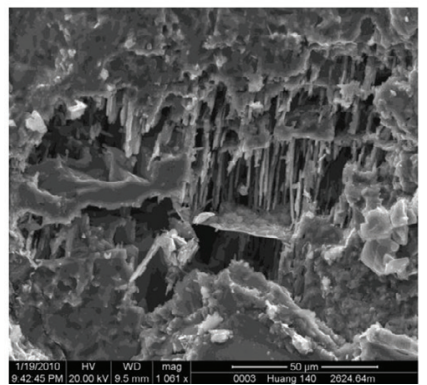

p)

Figure 8

(Continued) 


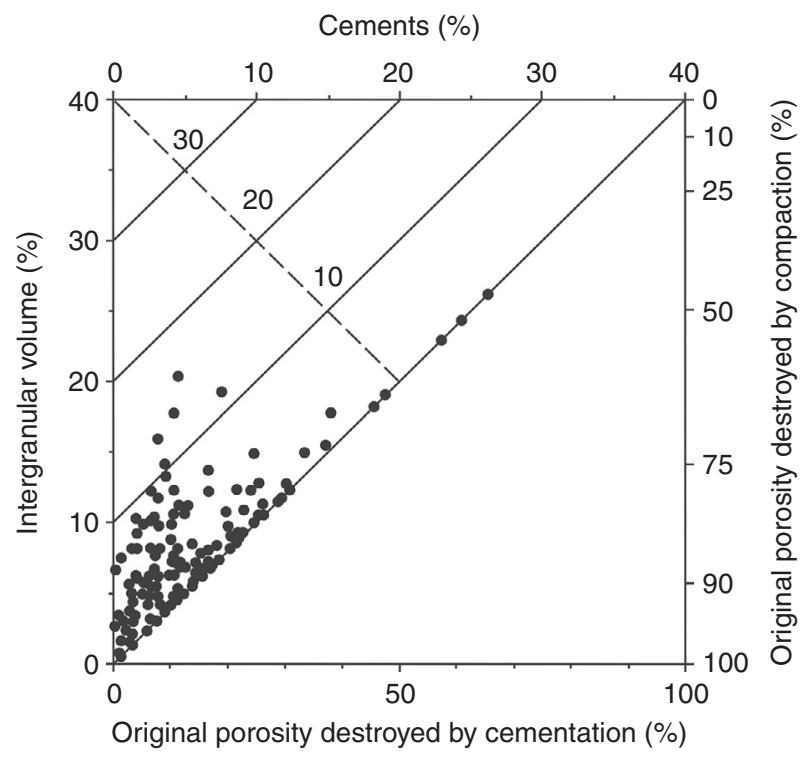

Figure 9

Plot of InterGranular Volume (IGV) versus volume of cement. Note that destruction of porosity by mechanical compaction was more significant than by cementation.

(Fig. 10g, h) and carbonate cementation diagenetic facies (Fig. 10i, j). Diagenetic facies have different diagenetic combinations and porosities (Lai et al., 2013a).

\subsection{Log Response of Various Diagenetic Reservoir Facies}

For years, research on diagenetic reservoir facies has been confined primarily to core and microscopic thin-section analyses (Zeng et al., 2013). Diagenetic variations have not been previously correlated with core petrophysics and well-log response (Ozkan et al., 2011). However, different diagenetic reservoir facies have discrepancies related with macro petrological and mineralogical characteristics. Such discrepancies result in different response characteristic of diagenetic facies in different logging curves and their combinations, which are the theoretical basis of diagenetic facies recognition and detection using well log curves (Zhang et al., 2012; Shi et al., 2011; Lai et al., 2013c), in other words, diagenetic facies can be defined by a set of $\log$ responses, with the value ranges of bulk density, neutron, sonic, and GR logs (Ozkan et al., 2011). For example, carbonate cemented intervals (high apparent cementing rate) are identified by low-density porosity, clay matrix-and pseudomatrix-rich sandstones and mica-rich sandstones (compaction was more effective) and also have high bulk densities, but their GR and CNL values are significantly higher than carbonate cemented intervals, while clean sandstones (clay matrix-free) tend to have lower GR readings (Ozkan et al., 2011). Therefore, by translating diagenetic facies to $\log$ responses, a model can be generated, and it could be used to predict the likely diagenetic facies in nearby wells which lack core control with the same or similar log responses (Ozkan et al., 2011).

Based on diagenetic facies classification and combination of core thin section and logging data, the wire line logging response characteristics of five different diagenetic facies can be summarized. Conventional logging curves that are highly sensitive to diagenetic facies include acoustic time (AC), natural Gamma (GR), Bulk Density (DEN), Compensated Neutron Log (CNL), and Resistivity Logging (RT) (Lai et al., 2013a, c). Bulk density, AC, RT, CNL are plotted against GR (Fig. 11). Because each diagenetic facies is defined by a distinct range in a set of log responses, especially DEN, RT and GR, these open well logs are the most helpful tools in predicting diagenetic facies. The range of well-log parameters of various diagenetic facies is provided in Figure 11 and Table 1. The diagenetic facies are defined by a set of $\log$ responses in this way, and the diagenetic facies can be predicted with this generated model (Ozkan et al., 2011).

\subsubsection{Carbonate Cementation Diagenetic Facies}

Carbonate cementation is a common and important diagenetic alteration that has profound impact on reservoir heterogeneity and quality (Dutton and Loucks, 2010; Mansurbeg et al., 2008; Loyd et al., 2012); it often contributes to the poor reservoir quality. Thin section porosity of carbonate cementation diagenetic facies are very low due to the extensive carbonate cements (Fig. 10i, j).

Extensive carbonate cementation can be detected in resistivity logs because of the high resistivity values $(>50 \Omega \cdot \mathrm{m})$ encountered (Fig. 11b). High resistivity values of carbonate cementation layer also correspond to high bulk density $\left(>2.58 \mathrm{~g} / \mathrm{cm}^{3}\right)$ and low GR values ( $\left.<75 \mathrm{API}\right)$, indicating that the reservoir quality is diminished in the presence of diagenetic carbonate cements (Fig. 11a). Previous studies confirmed that carbonate cement is interpreted to occur where the well-log neutron porosity exceeds the density porosity by more than 7\% (Atchley et al., 2010). However, for Chang 8 sandstones, the CNL values of carbonate cementation diagenetic facies are generally lower than $20 \%$ due to the absence of clays and clay minerals, also the $\mathrm{AC}$ values of this type of diagenetic facies are low, showing the sandstones are tightly cemented by carbonate cements (Fig. 11c, d). Generally, carbonate cementation diagenetic facies are easy to identify with their high bulk density, low GR readings, high resistivity values, low neutron porosity and low AC values (Fig. 11c). 


\subsubsection{Tight Compaction Diagenetic Facies}

Cumulative effect of mechanical compaction due to progressive burial results in a rapid decrease in porosity in the early diagenetic stage (Gier et al., 2008). Compaction is more penetrative where ductile grains are abundant (Ozkan et al., 2011). The rate of porosity reduction was higher for lithic-rich or detrital clay-rich samples due to the abundance of malleable grains. Fine-grained sandstone units are also strongly influenced by tight mechanical compaction (Mckinley et al., 2011; Mansurbeg et al., 2012). There is also a greater degree of compaction in poorly sorted sandstones since the smaller grains could fit into the pores between the relatively larger grains, leading to porosity reduction (Mckinley et al., 2011; Walderhaug et al., 2012). Poorly sorted sand with silt and clay can however be mechanically compacted to low porosity compounds at moderate burial depth and stress (Bjørlykke, 2014). Thin section porosity of tight compaction diagenetic facies is also very low due to the high degree of compaction (Fig. 10e, f).

Tight compaction diagenetic facies mainly develop in lithofacies rich in, micas, detrital clay and soft rock fragments, and

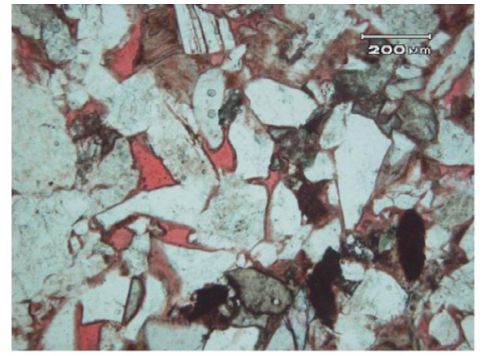

a)

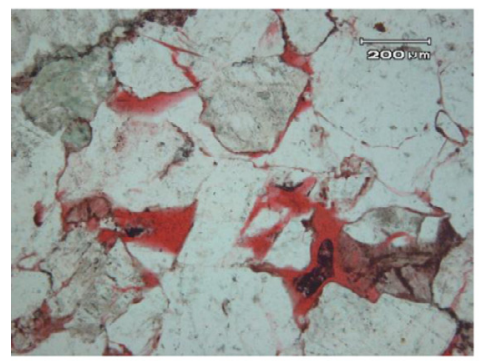

c)

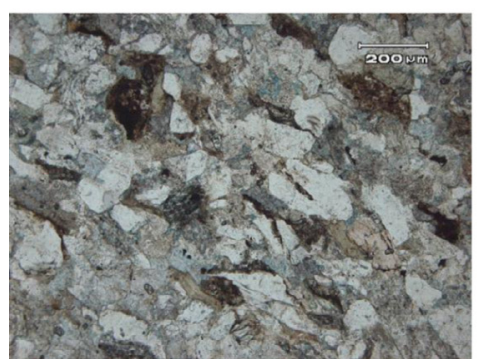

e)

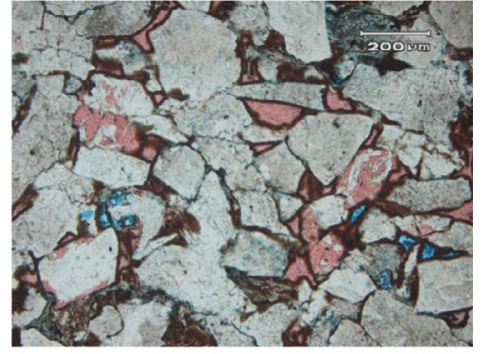

b)

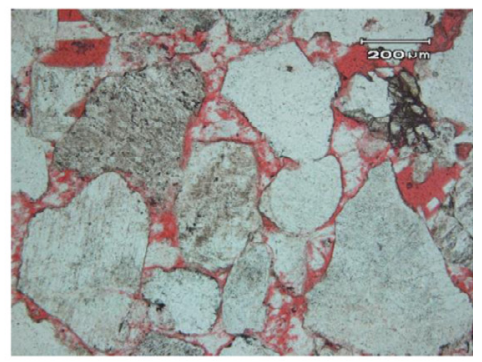

d)

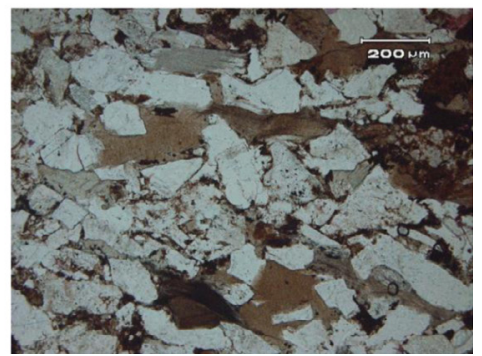

f)

Figure 10

Diagenesis facies characteristics of Chang 8 sandstones in Jiyuan Area: a) grain-coating chlorite-weak dissolution diagenetic facies, grain-coating chlorite around the quartz grains, primary porosity is preserved, Luo 8, $2650.51 \mathrm{~m}$, PPL; b) grain-coating chlorite-weak dissolution diagenetic facies, Yuan 181, $2024.55 \mathrm{~m}$, PPL; c) unstable component dissolution diagenetic facies, intergranular macropores are relatively common in this sandstone, some feldspar grains contain intragranular micropores due to the partial grain dissolution, Yuan 183, 2 895.06 m, PPL; d) unstable component dissolution diagenetic facies, intergranular macropores are commonly seen, some feldspargrains and rock fragments are microporous due to the partial grain dissolution, Feng 4, $2267.5 \mathrm{~m}$, PPL; e) tight compaction diagenetic facies, relatively soft rock fragments mostly show concave-convex grain contacts; quartz and feldspar grains usually exhibit planar grain contacts, deformation of micas, Luo 32 , 2 857.8 m, PPL; f) tight compaction diagenetic facies, deformation of micas, framework grains are heavily compacted, as indicated by the common planar and concave-convex grain contacts, Yuan 189, 2220.02 m, PPL; g) clay minerals (mainly kaolinite) filling diagenetic facies, vermicular kaolinite aggregates, Huang 3, $2571.42 \mathrm{~m}$; h) clay minerals (mainly kaolinite) filling diagenetic facies, SEM images showing vermicular kaolinite aggregate, Luo 17, $2829.18 \mathrm{~m}$; i) calcite (stained in red) occludes intergraular pores, the sandstones are generally tight, floating grain texture, Yuan 153, 2386.85 m, PPL; j) calcite (stained in red) occludes intergraular pores, Luo 1, 2499.07 m, PPL. 


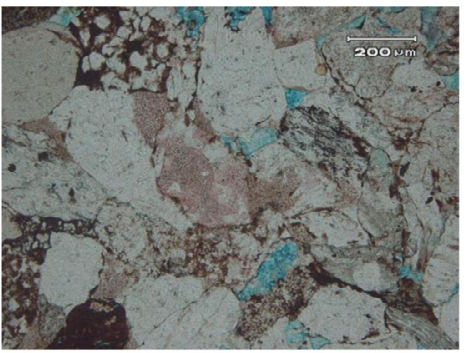

g)

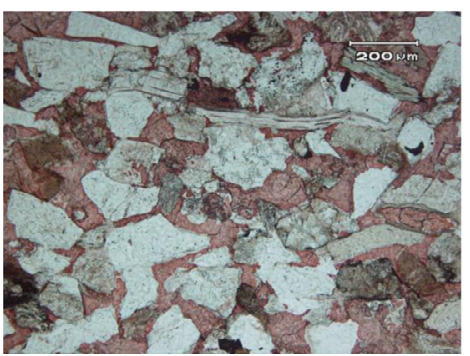

i)

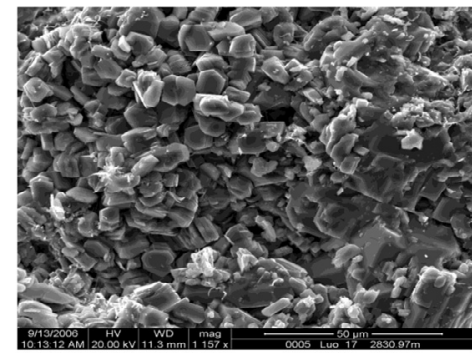

h)

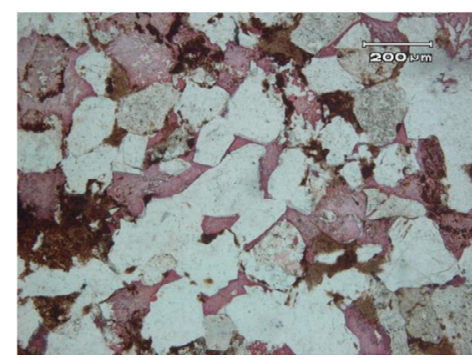

j)

Figure 10

(Continued)

these low-energy fine-grained, clay-rich sandstones often have poorer quality than higher energy, well-sorted and relatively coarser grained sandstones (Zhang et al., 2008). Because of the effect of clays, micas and rock fragments, GR readings for tight compaction diagenetic facies are highest ( $>100$ API averaged), and neutron porosities are relatively middle to high (Fig. 11). These clay and mica rich sandstones also have high bulk densities due to the tight compaction in the geological history, indicating a poor reservoir property, however, their GR readings are significantly higher than the carbonate cemented intervals (Ozkan et al., 2011). Furthermore the tight compaction diagenetic facies can be recognized by the low-resistivity responses (Fig. 11a, b).

\subsubsection{Clay Minerals Filling Diagenetic Facies}

The abundance of authigenic clay minerals played a strong role in controlling the reservoir quality, for example, the fibrous and webby morphology of illite and MILS block pore throats or bridge pores may significantly reduce the permeability of a deeply buried sandstone (Mckinley et al., 2011; Ajdukiewicz and Lander, 2010). Together with carbonate cements, clay minerals cementation (pore filling kaolinite, illite and MILS) is among the most damaging diagenetic processes for petrophysical properties of Chang 8 sandstones. The pore systems of clay minerals filling diagenetic facies are dominated by micropores associated with the pore-filling authigenic clays (Fig. $10 \mathrm{~g}, \mathrm{~h}$ ).

Compared with tight compaction diagenetic facies, clay minerals filling diagenetic facies generally have lower clay (mainly authigenic) content, so the GR readings are on average 89 API (Fig. 11), however, the neutron porosity gives unreasonably high porosities $(>20 \%)$ because of clay effects (Fig. 11d). SEM analyses reveal that authigenic clays occur in the form of pore filling, and considerable amounts of micro-porosity are assumed to exist in the authigenic minerals, especially the vermicular kaolinite aggregates, so the neutron porosity is relatively high and the bulk density is relatively low $\left(<2.55 \mathrm{~g} / \mathrm{cm}^{3}\right.$; Fig. 11a, d); in which over prediction of porosity reaches more than $10 \%$, however, their GR values are also relatively high ( $>80 \mathrm{API})$.

\subsubsection{Grain-Coating Chlorite Weak Dissolution Diagenetic Facies}

Although the thin, chloritic grain coatings occupy a small volume of the pore space, primary porosity is better preserved in these sandstones because of inhibition of quartz precipitation by grain-coating chlorites (Ozkan et al., 2011). In addition, the dissolution intensity is closely related to the preservation of primary pores and the flow of pore fluid (Zou et al., 2008). Grain-coating sandstones with high compaction resistance may preserve more primary pores, and this is favorable to pore fluid flow and framework grains dissolution (Zou et al., 2008). Pore systems of grain-coating chlorite weak dissolution diagenetic facies are dominated by intergranulary pores and minor dissolution pores (Fig. 10a, b). This is consistent with microscopic observations, see Figure $10 \mathrm{a}, \mathrm{b}$, for which the high thin section porosities are of both primary and secondary origins. 

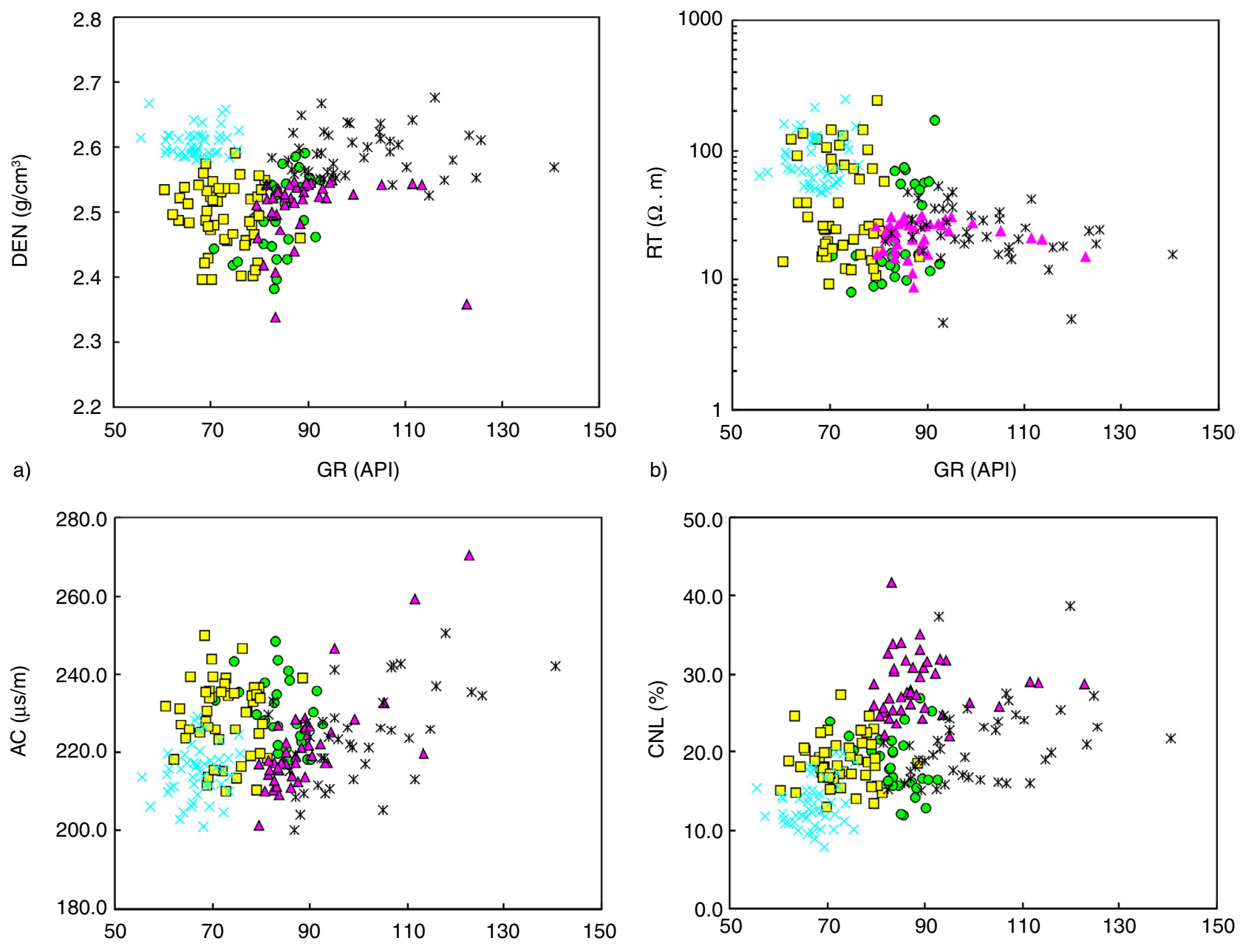

c)

$$
\text { GR (API) }
$$

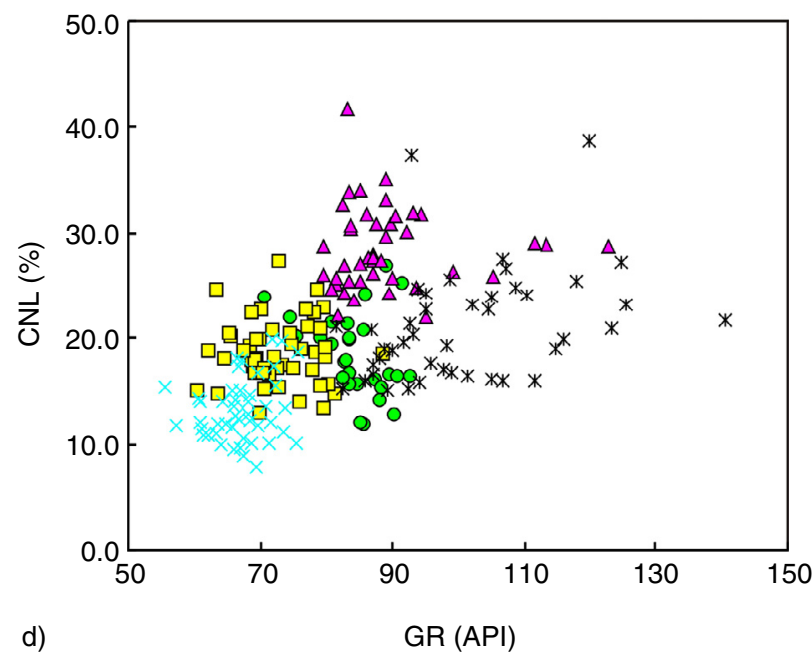

Grain-coating chlorite weak dissolution diagenetic facies

$\square$ Unstable component dissolution diagenetic facies

$\Delta$ Clay minerals fikking diagenetic facies $\times$ Carbonate cementation diagenetic facies

Wight compaction diagenetic facies

Figure 11

Plots of gamma ray versus a) bulk density, b) deep resistivity, c) AC and d) CNL values.

Sandstones with grain-coating chlorite weak dissolution diagenetic facies are characteristic of low-middle GR readings (70-90 API; Fig. 11), and a wide range of resistivity values (resistivity values from 7.9 to $170.2 \Omega \cdot \mathrm{m}$; Fig. 11b). Commonly, these sandstones have a RT reading less than $20 \Omega \cdot \mathrm{m}$, however, when this diagenetic facies corresponds to the oil bearing layers, high resistivity values $(>50 \Omega \cdot \mathrm{m})$ are also encountered (Fig. 11b, Tab. 1). Bulk density of this diagenetic facies is low $\left(<2.6 \mathrm{~g} / \mathrm{cm}^{3}\right.$; Fig. 11a). This is different for carbonate cementation diagenetic facies, where CNL values range from 11 to $27 \%$ (Fig. $11 \mathrm{~d}$ ), and the $\mathrm{AC}$ values are high $(>220 \mu \mathrm{s} / \mathrm{m}$; Fig. 11C). All these parameters indicate that the reservoir quality of this diagenetic facies is good.
This feature was also helpful in discriminating clay minerals filling diagenetic facies.

\subsubsection{Unstable Component Dissolution Diagenetic Facies}

Reservoir quality of deeply buried sandstones can be enhanced to various extents owing to secondary porosity development which results from the dissolution of framework grains (Mansurbeg et al., 2008). Dissolution is generally associated with sandstones characteristic of medium-grained, well sorted, low clay and cement contents. Porosity can be enhanced to some extent only in the high energy clean sandstones (clay matrix-free) sandstones which are relatively coarse grained, 
well sorted and abundant in rigid grains (Bloch et al., 2002): this is consistent with petrographic observations (Fig. 10c, d). Unstable component dissolution diagenetic facies develop in sandstones in which the byproduct of silica and clay minerals is removed (reaction 1-3), so there is a net increase in porosity. Pore systems of this diagenetic facies are dominated by moldic and vuggy porosity resulting from framework grains dissolution (Fig. 10c, d). However, these secondary macropores are relatively poorly connected to the intergranular pore network, owing to the presence of feldspar remnants (Mansurbeg et al., 2012):

$$
\begin{gathered}
3 \mathrm{KAlSi}_{3} \mathrm{O}_{8}(\mathrm{~K} \text {-feldspar })+2 \mathrm{H}^{+}+\mathrm{H}_{2} \mathrm{O} \rightarrow \\
\mathrm{KAl}_{3} \mathrm{Si}_{3} \mathrm{O}_{10}(\mathrm{OH})_{2}(\text { illite })+6 \mathrm{SiO}_{2}(\mathrm{aq})+2 \mathrm{~K}^{+}+\mathrm{H}_{2} \mathrm{O}
\end{gathered}
$$

$$
\begin{gathered}
2 \mathrm{NaAlSi}_{3} \mathrm{O}_{8} \text { (plagioclase) }+2 \mathrm{CO}_{2}+3 \mathrm{H}_{2} \mathrm{O} \rightarrow \\
\mathrm{Al}_{2} \mathrm{Si}_{2} \mathrm{O}_{5}(\mathrm{OH})_{4}+4 \mathrm{SiO}_{2} \text { (quartz) }+2 \mathrm{Na}^{+}+2 \mathrm{HCO}_{3}^{-} \\
\mathrm{CaAl}_{2} \mathrm{Si}_{2} \mathrm{O}_{8} \text { (plagioclase) }+2 \mathrm{CO}_{2}+3 \mathrm{H}_{2} \mathrm{O} \rightarrow \\
\mathrm{Al}_{2} \mathrm{Si}_{2} \mathrm{O}_{5}(\mathrm{OH})_{4}+\mathrm{Ca}^{2+}+2 \mathrm{HCO}_{3}^{-}
\end{gathered}
$$

In general, these clean sandstones tend to have lower GR readings than that of grain-coating chlorite weak dissolution diagenetic facies, ranging between 60 and 88 with an average of 72 API (Fig. 11). High resistivity values $(>50 \Omega \cdot \mathrm{m}$; Fig. 11b) are also encountered in the unstable component dissolution diagenetic facies due to its higher oil potentials. Bulk density of this diagenetic facies is low $\left(<2.6 \mathrm{~g} / \mathrm{cm}^{3}\right.$; Fig. 11a), CNL values range from 13 to $27 \%$ (Fig. 8 d), and the $\mathrm{AC}$ values are high $(>210 \mu \mathrm{s} / \mathrm{m}$; Fig. $11 \mathrm{c})$.

\subsection{Diagenetic Facies versus Reservoir Quality}

Various diagenetic facies combinations result in different porosity characteristics and physical properties of reservoirs (Fu et al., 2009). Porosity and permeability ranges for each diagenetic facies were determined from core analyses. Correlation of diagenetic facies with petrophysical properties shows that sandstones with the poorest reservoir qualities in Chang 8 oil layers are tightly cemented with carbonate or are rich in clay matrix, i.e., carbonate cementation diagenetic facies: tight compaction diagenetic facies have the lowest porosities and lowest permeabilities (Fig. 12). Sandstones of the highest reservoir quality are those with chlorite grain-coating clays that inhibit quartz

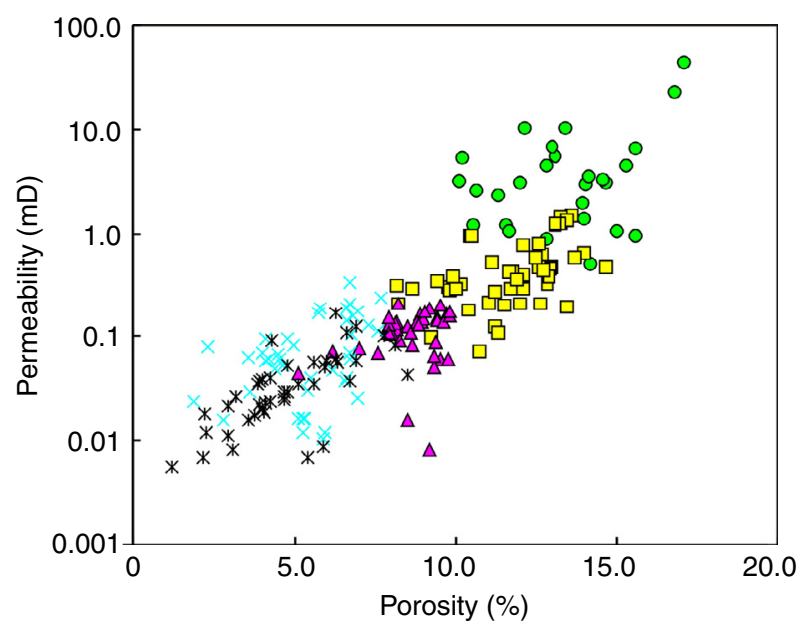

Figure 12

Core-measured porosity versus permeability crossplot for various diagenetic facies. The legend is shown in Figure 11.

TABLE 1

Well logging response characteristics of various diagenetic facies of Chang 8 sandstones in Jiyuan Area

\begin{tabular}{c|c|c|c|c|c}
\hline Diagenetic facies & GR (API) & AC $\left(\mu \mathrm{s} \cdot \mathrm{m}^{-1}\right)$ & CNL $(\%)$ & DEN $\left(\mathrm{g} \cdot \mathrm{cm}^{-3}\right)$ & $2.38-2.59$ \\
\hline $\begin{array}{c}\text { Grain-coating chlorite } \\
\text { weak dissolution } \\
\text { facies }\end{array}$ & $70-90$ & $220-250$ & $12-27$ & $2.40-2.59$ & $>8.0$ \\
\hline $\begin{array}{c}\text { Unstable component } \\
\text { dissolution facies }\end{array}$ & $60-88$ & $210-250$ & $13-27$ & $>2.55$ & $9-240$ \\
\hline $\begin{array}{c}\text { Tight compaction } \\
\text { facies }\end{array}$ & $80-140$ & $200-250$ & $22-42$ & $2.34-2.55$ & $<30.0$ \\
\hline $\begin{array}{c}\text { Clay minerals filling } \\
\text { facies }\end{array}$ & $80-120$ & $200-260$ & $<20$ & $>2.60$ & $>30.0$ \\
\hline $\begin{array}{c}\text { Carbonate } \\
\text { cementation facies }\end{array}$ & $55-75$ & $<230$ & & $<0.0$ \\
\hline
\end{tabular}




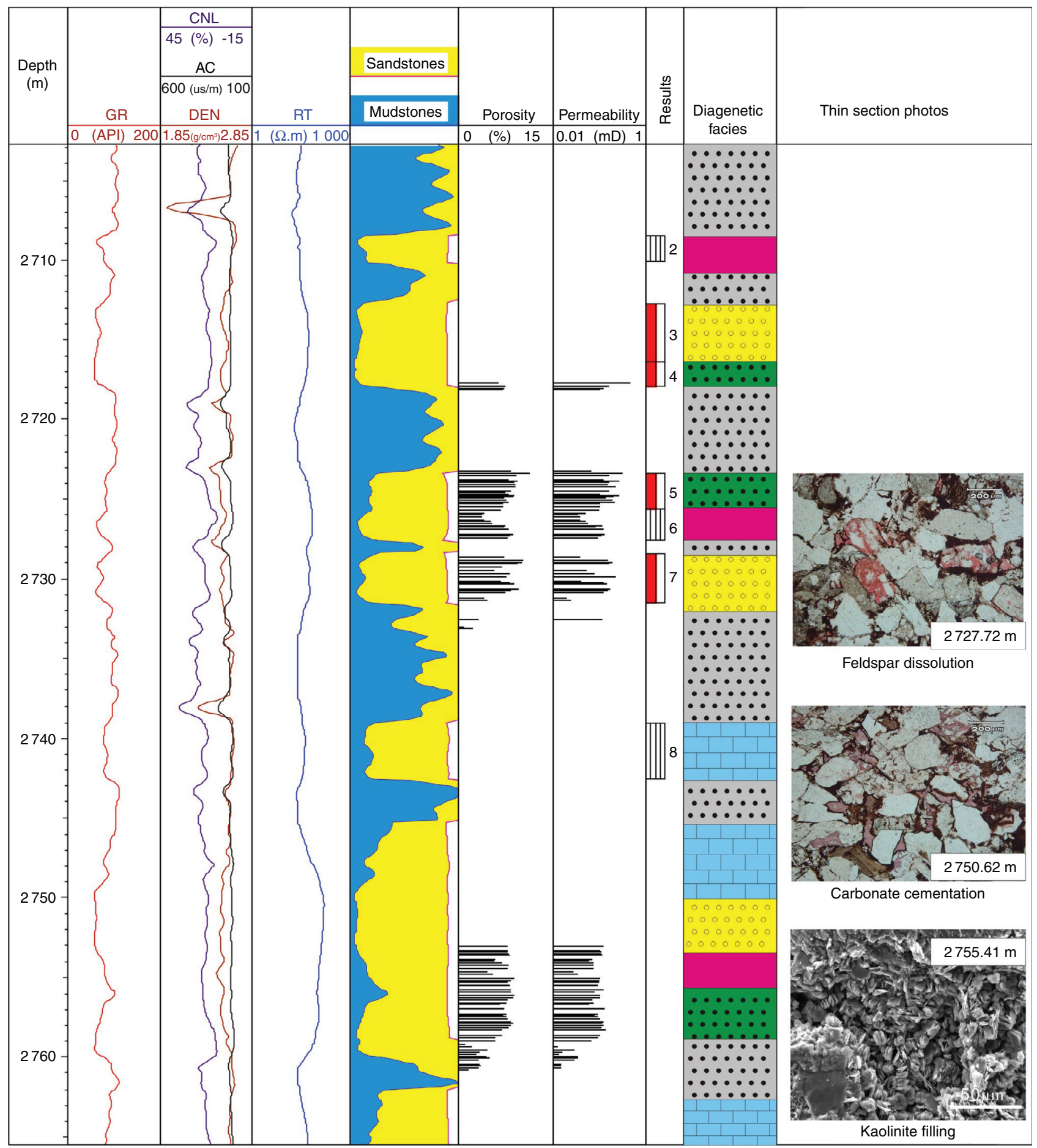

$\therefore \because \therefore$ Grain-coating chlorite weak dissolution

Unstable component dissolution

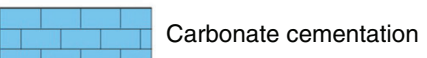

$\because \because \because \because$ Tight compaction

Clay minerals filling facies

Figure 13

The vertical division of diagenetic facies in Well Luo 13. 


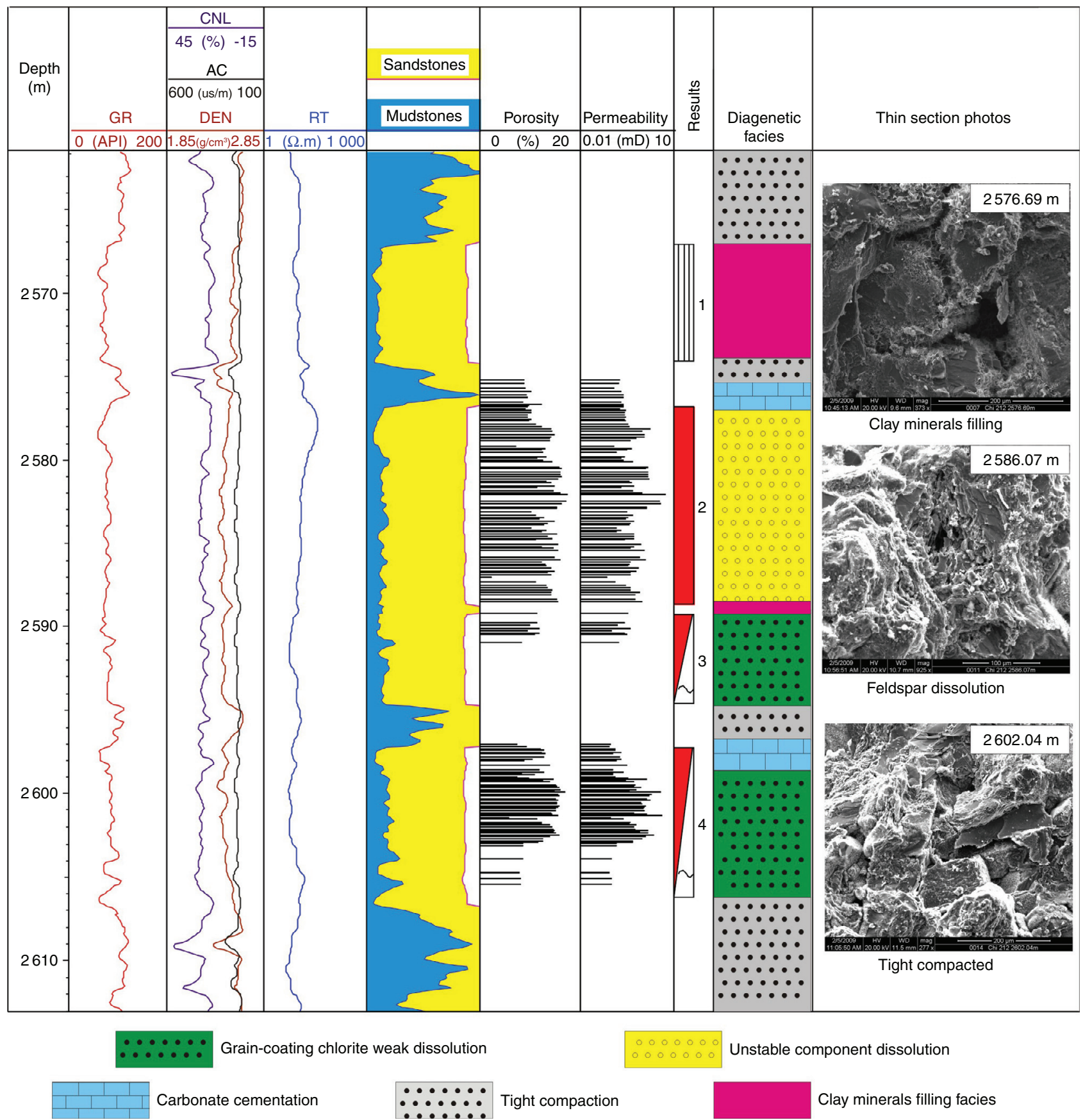

Figure 14

The vertical division of diagenetic facies in Well Chi 212.

cementation, and those with clean sandstones are abundant in the secondary dissolution porosity but rare in clay minerals (Fig. 12). These two diagenetic facies correspond to the main high quality reservoirs and oil bearing layers in Chang 8 tight reservoirs. Sandstones for clay minerals filling diagenetic facies have middle porosity and middle - to low permeability values (Fig. 12), and the low permeability is mainly caused by micropores that dominate the pore system as confirmed by petrography and SEM studies.

The permeability of grain-coating chlorite weak dissolution diagenetic facies is relatively high compared to unstable component dissolution diagenetic facies (Fig. 12). 
Permeability is mainly controlled by intergranular macroporosity and pore-throat size, not by pore space morphology (Midtbø et al., 2000; Bloch et al., 2002). The primary intergranular pores in grain-coating chlorite weak dissolution diagenetic facies, connected by larger pore throats compared to the secondary pores, favour the higher reservoir quality in grain-coating facies (Dutton and Loucks, 2010).

\subsection{Diagenetic Facies in a Single Well}

To evaluate the accuracy of the predictive model of diagenetic facies, a blind test was administred from two cored wells within the study area that had not been included within the database used to develop the well-log facies. Based on the interpretation of diagenetic facies from cores and thin sections observations, and the translation diagenetic facies to well $\log$ responses, vertical profile distribution rule of diagenetic facies in each well can be predicted. A software FORWARD (Formation Oil and Gas Reservoir Well logging Analysis and Research and Development) is used in China to predict the diagenetic facies in a single well. According to the well logging response, characteristics of various diagenetic facies are summarized in Figure 8 and Table 1. Diagenetic facies is predicted from comprehensively analyzing the combination characteristics of well logs. For the Well Luo 13 and Chi 212 as examples, actual log data of these two wells were processed using the generated model, and the diagenetic facies is predicted on the vertical profile. The predicted distribution of diagenetic facies precisely coincides with the microscopic observations (Fig. 13, 14). By the coupling of carbonate cementation and mechanical compaction (tight compaction diagenetic facies) control the ultimate reservoir property of Chang 8 sandstones, these two diagenetic facies mainly correspond to the non-reservoir and dry layers, while the layers with higher oil potentials are mainly developed in the grain-coating chlorite diagenetic facies (Fig. 13, 14). In general, diagenetic processes in Chang 8 sandstones are generally locally distributed, reflecting the sediment composition, temperature history and effective stress (Bjørlykke, 2014). By translating diagenetic facies to well log responses, diagenetic facies and further reservoir quality of intervals that lack core control, could be predicted with the same or similar log responses.

\section{CONCLUSIONS}

A model that uses GR, bulk density, neutron, and sonic logs and their ratios as variables is designed to identify diagenetic facies from well logs.

Five types of diagenetic facies are selected based on type and degree of diagenesis, diagenetic minerals assemblages and their effect on the reservoir quality. They are: grain-coating chlorite-weak dissolution facies, unstable component dissolution facies, tight compaction facies, clay minerals filling facies and carbonate cementation facies.

Carbonate cementation facies are identified by low GR, high bulk density, high resistivity values, low $\mathrm{AC}$ and CNL values.

Tight compaction facies can be recognized by their highest GR readings, high bulk density, low resistivity values, high $\mathrm{AC}$ and $\mathrm{CNL}$ values.

Clay minerals filling facies are characteristic of high GR, low bulk density, low resistivity, and relatively high CNL values.

Unstable component dissolution facies are identified by low GR readings, wide range of RT values, low bulk density, high $\mathrm{AC}$ values and middle to high CNL values.

Grain-coating chlorite weak dissolution diagenetic facies are characteristic of low-middle GR readings (higher than unstable component dissolution facies), a wide range of resistivity values, low bulk density, high AC values and middle to high CNL values.

Correlation of diagenetic facies with petrophysical properties shows that sandstones with the poorest reservoir qualities in Chang 8 oil layers are associated with carbonate cementation diagenetic facies and tight compaction diagenetic facies. Unstable component dissolution facies and grain-coating chlorite weak dissolution diagenetic facies correspond to the main high quality reservoirs and oil bearing layers in Chang 8 tight reservoirs.

The accuracy of the predictive model of diagenetic facies was evaluated by a blind test conducted on two cored wells within the study area that had not been included within the database used to develop the well-log facies. The predicted results of diagenetic facies precisely coincides with the microscopic observations.

\section{ACKNOWLEDGMENTS}

We thank PetroChina Changqing Oilfield Company for providing samples and data access and for permission to publish this work. We are indebted to the anonymous reviewers and the editors for their constructive comments, which improve the paper significantly. This work was financially supported by the National Science \& Technology Major Project of China (Grant No. 2011ZX05020-008) and National Natural Science Foundation of China (Grant No. 41472115), we thank the sponsors of these projects.

\section{REFERENCES}

Ajdukiewicz J.M., Lander R.H. (2010) Sandstone reservoir quality prediction: The state of the art, AAPG Bulletin 94, 8, 1083-1091.

Atchley S.C., Ball N.H., Hunt L.E. (2010) Reservoir characterization and facies prediction within the Late Cretaceous Doe Creek Member, Valhalla field, west-central Alberta, Canada, AAPG Bulletin 94, 1, 1-25. 
Beard D.C., Weyl P.K. (1973) Influence of texture on porosity and permeability of unconsolidated sand, AAPG Bulletin 57, 349-369.

Bjørlykke K. (2014) Relationships between depositional environments, burial history and rock properties. Some principal aspects of diagenetic process in sedimentary basins, Sedimentary Geology 301, 1-14.

Bloch S., Lander R.H., Bonnell L. (2002) Anomalously high porosity and permeability in deeply buried sandstone reservoirs: Origin and predictability, AAPG Bulletin 86, 2, 301-328.

Deschamps R., Kohler E., Gasparrini M., Durand O., Euzen T., Nader F. (2012) Impact of mineralogy and diagenesis on reservoir quality of the Lower Cretaceous Upper Mannville Formation (Alberta, Canada), Oil \& Gas Science and Technology 67, 1, 31-58.

Dickinson W.R., Suczek C.A. (1979) Plate tectonics and sandstones composition, American Association of Petroleum Geologists Bulletin 63, 2164-2182.

Dou W.T., Liu X.S., Luo J.L., Du J.L., Wang T. (2010) Relationship of Slope-Break, Slope Type with Hydrocarbon Pool-Forming of the Upper Triassic from Jiyuan Area, the Northwestern Ordos Basin, Acta Sedimentologica Sinica 28, 6, 1129-1134 (in Chinese).

Duan Y., Wang C.Y., Zheng C.Y., Wu B.X., Zheng G.D. (2008) Geochemical study of crude oils from the Xifeng oilfield of the Ordos basin, China, Journal of Asian Earth Sciences 31, 341-356.

Duan Y. (2012) Geochemical characteristics of crude oil in fluvial deposits from Maling oilfield of Ordos basin, China, Organic Geochemistry 52, 35-43.

Duan Y., Yuan Y., Qian R. (2013) Migration features of crude oil in fluvial deposits of Maling oilfield in Ordos basin, China, Organic Geochemistry 58, 78-85.

Dutton S.P., Loucks R.D. (2010) Diagenetic controls on evolution of porosity and permeability in lower Tertiary Wilcox sandstones from shallow to ultradeep (200-6700 m) burial, Gulf of Mexico Basin, U.S.A, Marine and Petroleum Geology 27, 69-81.

Ehrenberg S.N., Nadeau P.H., Steen Ø. (2009) Petroleum reservoir porosity versus depth: Influence of geological age, AAPG Bulletin 93, 10, 1281-1296.

Folk R.L. (1974) The petrology of sedimentary rocks, Hemphill Publishing Co., Austin, Texas, 182 p.

Fu G.M., Qin X.L., Miao Q., Zhang T.J., Yang J.P. (2009) Division of diagenesis reservoir facies and its control: Case study of Chang-3 reservoir in Yangchang formation of Fuxian exploration area in northern Shaanxi, Mining Science and Technology 19, 537-543.

Gier S., Worden R.H., Johns W.D., Kurzweil H. (2008) Diagenesis and reservoir quality of Miocene sandstones in the Vienna Basin, Austria, Marine and Petroleum Geology 25, 681-695.

Guo S. (2013) Experimental study on isothermal adsorption of methane gas on three shale samples from Upper Paleozoic strata of the Ordos basin, Journal of Petroleum Science and Engineering 110, 132-138.

Guo Y.R., Liu J.B., Yang H., Liu Z., Fu J.H., Yao J.L., Xu W.L., Zhang Y.L. (2012) Hydrocarbon accumulation mechanism of low permeable tight lithologic oil reservoirs in the Yanchang Formation, Ordos basin, China, Petroleum Exploration and Development 39, 4, 417-425 (in Chinese with English abstract).

Higgs K.E., Zwingmann H., Reyes A.G., Funnell R.H. (2007) Diagenesis, porosity evolution, and petroleum emplacement in tight gas reservoirs, Taranaki basin, New Zealand, Journal of Sedimentary Research 77, 1003-1025.
Islam M.A. (2009) Diagenesis and reservoir quality of Bhuban sandstones (Neogene), Titas Gas Field, Bengal Basin, Bangladesh, Journal of Asian Earth Sciences 35, 89-100.

Ji L., Meng F., Schiffbauer J.D., Xu J., Yan K., Shu J. (2008) Correlation between highly abundant oil-prone leiosphaerid acritarchs and hydrocarbon source rocks from the Triassic Yanchang Formation, eastern Gansu Province, Northwestern China, Gondwana Research 14, 554-560.

Ji L., Yan K., Meng F., Zhao M. (2010) The oleaginous Botryococcus from the Triassic Yanchang Formation in Ordos basin, Northwestern China: Morphology and its paleoenvironmental significance, Journal of Asian Earth Sciences 38, 175-185.

Jiang Z.X., Xu J., Wang G.T. (2012) The discovery and significance of a sedimentary hiatus within the Carboniferous Taiyuan Formation, northeastern Ordos basin, China, AAPG Bulletin 96, 7, 1173-1195.

Lai J., Wang G.W., Chen M., Wang S.N., Chai Y., Cai C., Zhang Y.C., Li J.L. (2013a) Pore structures evaluation of low permeability clastic reservoirs based on petrophysical facies, Petroleum Exploration and Development 40, 5, 566-573.

Lai J., Wang G.W., Wang S.N., Zheng Y.Q., Wu H., Zhang Y.C. (2013b) Research status and advances in the diagenetic facies of clastic reservoirs, Advances in Earth Science 28, 1, 39-50 (in Chinese with English abstract).

Lai J., Wang G.W., Wang S.N., Xin Y., Wu Q.K., Li J.L., Cang D. (2013c) Overview and research progress in logging recognition method of clastic reservoir diagenetic facies, Journal of Central South University (Science and Technology) 44, 12, 4942-4953 (in Chinese with English abstract).

Li J., Zhang W., Luo X., Hu G. (2008) Paleokarst reservoirs and gas accumulation in the Jingbian field, Ordos basin, Marine and Petroleum Geology 25, 401-415.

Lima R.D., De Ros L.F. (2002) The role of depositional setting and diagenesis on the reservoir quality of Devonian sandstones from the Solimões Basin, Brazilian Amazonia, Marine and Petroleum Geology 19, 1047-1071.

Liu Q.S., Chan L.S., Liu Q.S., Li H.X., Wang F., Zhang S.X., Xia X.H., Cheng T.J. (2004) Relationship between magnetic anomalies and hydrocarbon microseepage above the Jingbian gas field, Ordos basin, China, AAPG Bulletin 88, 2, 241-251.

Luo J.L., Morad S., Salem A., Ketzer J.M., Lei X.L., Guo D.Y., Hlal O. (2009) Impact of diagenesis on reservoir-quality evolution in fluvial and lacustrine-deltaic sandstones: evidence from Jurassic and Triassic sandstones from the Ordos basin, China, Journal of Petroleum Geology 32, 1, 79-102.

Loyd S.J., Corsetti F.K., Eiler J.M., Tripati A.K. (2012) Determining the diagenetic conditions of concretion formation: assessing temperatures and pore waters using clumped isotopes, Journal of Sedimentary Research 82, 1006-1016.

Mansurbeg H., Morad S., Salem A., Marfil R., El-ghali M.A.K., Nystuen J.P., Caja M.A., Amorosi A., Garcia G., Iglesia A.L. (2008) Diagenesis and reservoir quality evolution of palaeocene deep-water, marine sandstones, the Shetland-Faroes Basin, British continental shelf, Marine and Petroleum Geology 25, 514-543.

Mansurbeg H., De Ros R.L.F., Morad S., Ketzer J.M., El-ghali M. A.K., Caja M.A., Othman R. (2012) Meteoric-water diagenesis in late Cretaceous canyon-fill turbidite reservoirs from the Espírito Santo Basin, eastern Brazil, Marine and Petroleum Geology 37, $7-26$. 
Mckinley J.M., Atkinson P.M., Lloyd C.D., Ruffell A.H., Worden R.H. (2011) How porosity and permeability vary spatially with grain size, sorting, cement volume, and mineral dissolution in fluvial Triassic sandstones: the value of geostatistics and local regression, Journal of Sedimentary Research 81, 844-858.

Midtbø R.E.A., Rykkje J.M., Ramm M. (2000) Deep burial diagenesis and reservoir quality along the eastern flank of the Viking Graben: Evidence for illitization and quartz cementation after hydrocarbon emplacement, Clay Minerals 35, 227-237.

Morad S., Al-Ramadan K., Ketzer J.M., De Ros L.F. (2010) The impact of diagenesis on the heterogeneity of sandstone reservoirs: A review of the role of depositional facies and sequence stratigraphy, AAPG Bulletin 94, 8, 1267-1309.

Nguyen N.T.T., Jones S.J., Goulty N.R., Middleton A.J., Grant N., Ferguson A., Bowen L. (2013) The role of fluid pressure and diagenetic cements for porosity preservation in Triassic fluvial reservoirs of the Central Graben, North Sea, AAPG Bulletin 97, 8, 1273-1302.

Ozkan A., Cumella S.P., Milliken K.L., Laubach S.E. (2011) Prediction of lithofacies and reservoir quality using well logs, Late Cretaceous Williams Fork Formation, Mamm Creek field, Piceance Basin, Colorado, AAPG Bulletin 95, 10, 1699-1723.

Qiu X., Liu C., Mao G., Deng Y., Wang F., Wang J. (2014) Late Triassic tuff intervals in the Ordos basin, Central China: Their depositional, petrographic, geochemical characteristics and regional implications, Journal of Asian Earth Sciences 80, 48-160.

Shi Y.J., Xiao L., Mao Z.Q., Guo H.P. (2011) An identification method for diagenetic facies with well logs and its geological significance in low-permeability sandstones: A case study on Chang 8 reservoirs in the Jiyuan region, Ordos basin, Acta Petrolei Sinica 32, 5, 820-827 (in Chinese with English abstract).

Shuai Y., Zhang S., Mi J., Gong S., Yuan X., Yang Z., Liu J., Cai D. (2013) Charging time of tight gas in the Upper Paleozoic of the Ordos Basin, central China, Organic Geochemistry 64, 38-46.

Taylor T.R., Giles M.R., Hathon L.A., Diggs T.N., Braunsdorf N.R., Birbiglia G.V., Kittridge M.G., Macaulay C.I., Espejo I.S. (2010) Sandstone diagenesis and reservoir quality prediction: Models, myths, and reality, AAPG Bulletin 94, 8, 1093-1132.

Tobin R.C., McClain T., Lieber R.B., Ozkan A., Banfield L.A., Marchand A.M.E., McRae L.E. (2010) Reservoir quality modeling of tight-gas sands in Wamsutter field: Integration of diagenesis, petroleum systems, and production data, AAPG Bulletin 94, 8, 1229-1266.

Walderhaug D., Eliassen A., Aase N.E. (2012) Prediction of permeability in quartz-rich sandstones: examples from the Norwegian continental shelf and the Fontainebleau sandstone, Journal of Sedimentary Research 82, 899-912.

Wang C.Y., Wang C.Y., Liang X.W., Li S.X., Xin H.G., Zheng R.C. (2011) Diagenetic facies of the Chang 8 oil bearing layer of the Upper Triassic Yanchang Formation in the Jiyuan area, Ordos Basin, Acta Petrolei Sinica 32, 4, 514-596 (in Chinese with English abstract).
Yang Y., Li W., Ma L. (2005) Tectonic and stratigraphic controls of hydrocarbon systems in the Ordos basin: A multicycle cratonic basin in central China, AAPG Bulletin 89, 2, 255-269.

Zhang H.T., Shi Z., Shi Y.J., Wang L.L., He L.J. (2012) Diagenetic facies types and logging identification methods for low permeability tight sandstone reservoirs: a case study on the 8th member of Xiashihezi Formation in Sulige gasfield, Ordos basin, Oil \& Gas Geology 33, 2, 256-264 (in Chinese with English abstract).

Zhang J., Qin L., Zhang Z. (2008) Depositional facies, diagenesis and their impact on the reservoir quality of Silurian sandstones from Tazhong area in central Tarim Basin, western China, Journal of Asian Earth Sciences 33, 42-60.

Zhu H., Chen K., Liu K., He S. (2008) A sequence stratigraphic model for reservoir sand-body distribution in the Lower Permian Shanxi Formation in the Ordos Basin, northern China, Marine and Petroleum Geology 25, 731-743.

Zeng H.L., Zhu X.M., Zhu R.K., Zhang Q.S. (2013) Seismic prediction of sandstone diagenetic facies: Applied to Cretaceous Qingshankou Formation in Qijia Depression, Songliao Basin, East China, Petroleum Exploration and Development 40, 3, 287-295.

Zeng L.B., Li X.Y. (2009) Fractures in sandstone reservoirs with ultra-low permeability: A case study of the Upper Triassic Yanchang Formation in the Ordos Basin, China, AAPG Bulletin 93, 4, 461-477.

Zou C.N., Tao S.Z., Yuan X.J., Zhu R.K., Hou L.H., Wang L., Gao X.H., Gong Y.J. (2009) The formation conditions and distribution characteristics of continuous petroleum accumulations, Acta Petrolei Sinica 30, 3, 324-331 (in Chinese with English abstract).

Zou C.N., Tao S.Z., Zhou H., Zhang X.X., He D.B., Zhou C.M., Wang L., Wang X.S., Li F.H., Zhu R.K., Luo P., Yuan X.J., Xu C.C., Yang H. (2008) Genesis, classification and evaluation method of diagenetic facies, Petroleum Exploration and Development 35, 5, 526-540.

Zou C.N., Wang L., Li Y., Tao S., Hou L.H. (2013a) Deeplacustrine transformation of sandy debrites into turbidites, Upper Triassic, Central China, Sedimentary Geology 265-266, 143-155.

Zou C.N., Yang Z., Tao S.Z., Yuan X.J., Zhu R.K., Hou L.H., Wu S. T., Sun L., Zhang G.S., Bai B., Wang L., Gao X.H., Pang Z.L. (2013b) Continuous hydrocarbon accumulation over a large area as a distinguishing characteristic of unconventional petroleum: The Ordos Basin, North-Central China, Earth-Science Reviews 126, 358-369.

Manuscript submitted in March 2014
Manuscript accepted in December 2014
Published online in May 2015

Cite this article as: J. Lai, G. Wang, Y. Chai and Y. Ran (2016). Prediction of Diagenetic Facies using Well Logs: Evidences from Upper Triassic Yanchang Formation Chang 8 Sandstones in Jiyuan Region, Ordos Basin, China, Oil Gas Sci. Technol 71, 34. 